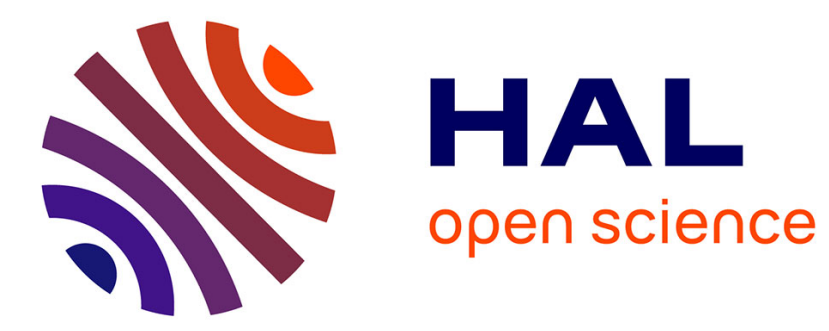

\title{
Tell Feres, a failed pathway towards urbanism in Northern Mesopotamia
}

\author{
Regis Vallet
}

\section{To cite this version:}

Regis Vallet. Tell Feres, a failed pathway towards urbanism in Northern Mesopotamia. Etudes mésopotamiennes-Mesopotamian Studies, 2018. hal-03088139

\section{HAL Id: hal-03088139 \\ https://hal.science/hal-03088139}

Submitted on 2 Jan 2021

HAL is a multi-disciplinary open access archive for the deposit and dissemination of scientific research documents, whether they are published or not. The documents may come from teaching and research institutions in France or abroad, or from public or private research centers.
L'archive ouverte pluridisciplinaire HAL, est destinée au dépôt et à la diffusion de documents scientifiques de niveau recherche, publiés ou non, émanant des établissements d'enseignement et de recherche français ou étrangers, des laboratoires publics ou privés. 


\title{
Études Mésopotamiennes - Mesopotamian Studies
}

$\mathrm{N}^{\circ}{ }_{1}-2018$

\author{
Direction \\ Vincent Déroche, Maria Grazia Masetti-Rouault \\ et Christophe Nicolle
}

Secrétariat de rédaction

Narmen Ali Muhamad Amen, Lionel Marti, Olivier Rouault, Aline Tenu 


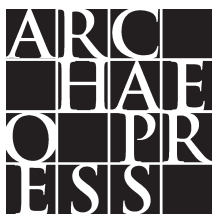

ARCHAEOPRESS PUBLISHING LTD

Summertown Pavilion

18-24 Middle Way

Summertown

Oxford OX2 7LG

www.archaeopress.com

ISSN 2631-3537 (Print)

ISSN 2631-3545 (Online)

ISBN 9781784919412 (Print)

ISBN 9781784919429 (e-Pdf)

(C) Archaeopress and the individual authors 2018

Cover: Tête de figurine en argile cuite / Terracotta figurine head (ㄷ Mission Archéologique Française à Qasr Shemamok - Kilizu).

All rights reserved. No part of this book may be reproduced, or transmitted, in any form or by any means, electronic, mechanical, photocopying or otherwise, without the prior written permission of the copyright owners.

Printed in England by Holywell Press, Oxford

This book is available direct from Archaeopress or from our website www.archaeopress.com 


\section{Sommaire}

Liste des auteurs du présent volume

Avant-propos

Le comité éditorial / The editorial board

A- Publication du Colloque Archéologie et Histoire des empires : modèles, projets et travaux en cours en Mésopotamie du Nord. Nouveaux programmes au Kurdistan d'Irak

Présentation et programme du Colloque international

Maria Grazia MASETTI-ROUAULT

New Perspectives in Archaeology in Iraqi Kurdistan.

Abubakir O. ZAINADIN (MALA AWAT)

Heritage conservation and traditional houses: problems and solutions

Nader Babakr MOHAMMED

Welcoming Archaeological Projects in Iraqi Kurdistan:

The Kurdish Point of View.

Gouhar SHEMDIN

Slemani Museum and its History

Hashim Hama ABDULLAH

Rethinking Assyrian History: New Archaeological Research at Qasr Shemamok, Iraqi Kurdistan (2011-2013). 47

Maria Grazia MASETTI-ROUAULT

Quelques réflexions autour des fouilles à Kilizu, aujourd'hui Qasr Shemamok

(Erbil, Kurdistan d'Iraq) : ville et territoire

Pedro AZARA, Joan BORRELL, Marc MARÍN et Eric RusiÑol

The Ancient History of the City of Erbil ab urbe condita to the coming of Alexander

John MACGINNIS

An Ubaid Kiln at Tell Nader (Kurdistan Region in Iraq)

Konstantinos KOPANIAS

Rapport préliminaire sur la première campagne de fouilles à Kunara (Mission Archéologique du Peramagron 2012) niveaux fin Bronze Ancien, début Bronze Moyen.

Christine KEPINSKI

Prospection dans la haute vallée du Tanjaro (Mission archéologique du Peramagron 2011)

Aline TENU

Les voies de communication dans le pays assyrien : l'exemple de la plaine sud d'Erbil

(Kurdistan irakien) 110

Lionel MARTI et Christophe NICOLLE 
La cité sainte de Muṣașir dans les sources écrites

Mirjo SALVINI

Les décors des croix portatives de Bazyan

Narmen Ali MuHAmad AMEN et Alain DesReumauX

Une inscription hébraïque médiévale découverte dans le Bet Garmaï (Kurdistan d'Irak) 151

Alain J. DESREUMAUX

Tell Feres, a failed pathway towards urbanism

in Northern Mesopotamia

Régis VALLET

B- Varia

Étude numismatique de deux Fals nohasi atabékides de Tell Kilik Mishik, à Erbil 174

Narmen ALI MUHAMAD AMEN

Urbilum/Erbil and the Northern Frontier of the Ur III State 178

Piotr MICHALOWSKI

The Hinterland of the Arbil City: A Survey of Tell Baxçan, Iraqi Kurdistan 188

Karel NovÁČEK, Stefano VALENTINI, Petr ŠídA and Narmen Ali MuHAMAd AMEN

Qasr Shemamok-Kilizu (Kurdistan d'Irak), les campagnes de 2011

(9 avril-15 mai et 16 octobre-5 novembre) 212

Olivier RouAult, Maria Grazia MasetTi-RouAult, Ilaria CALInI, John MACGinNis, Jason UR et Quentin VITALE

Qasr Shemamok-Kilizu (Kurdistan d'Irak), les campagnes de 2012

(6 avril-20 mai et 11-31 octobre)

Olivier Rouault, Maria Grazia Masetti-Rouault, Narmen Ali Muhamad Amen, Pedro AzARA, Ilaria CALINI,

Pauline Kessouri, John MAcGinnis, Marc MaRÌn, Karel NovÁčEK, Eric RusiÑol et Jacek TOMCZYK

The Archaeological Character of an Imperial Frontier:

Assyrian Control Policy in the Hula Valley .304

Yifat THAREANI

Compte-rendu de Konstantinos Kopanias and John MacGinnis (eds) 2016, The Archaeology

of the Kurdistan Region of Iraq and Adjacent Regions 330

Catherine BRENIQUET 


\title{
Tell Feres, a failed pathway towards urbanism in Northern Mesopotamia
}

\author{
Régis VALLET
}

Recent research on Chalcolithic Northern Mesopotamia has focused on the notion and modalities of regionalized evolutionary processes. The evidence for local paths towards social complexity has proven to be a major outcome of excavations conducted over the last decades in northern Syria and southeastern Turkey. ${ }^{1}$ In the general Chalcolithic panorama, Iraqi Kurdistan is a little known territory. Despite some early research and recent reassessments, ${ }^{2}$ the Chalcolithic of the Zagros region is almost completely unknown. While there is no doubt that the numerous new projects conducted in the region will soon modify our understanding of the Chalcolithic, as well as of later 'imperial' periods discussed in the present conference, research still relies on results obtained in neighboring regions. In this respect, Tell Feres, in Syrian Djezirah, is a key site for the identification of regional patterns within the Northern Mesopotamian Chalcolithic, due to its long uninterrupted sequence and the large surface areas exposed during the excavations. This paper briefly presents the main results obtained, as they provide a sound regionalized comparative context for ongoing work on Chalcolithic Iraqi Kurdistan.

After five excavation seasons at Tell Feres (2006-2010), the site had just begun to show its full potential for our understanding of the development of proto-urban societies in northern Mesopotamia, and particularly the rural component of this important regional transformation. Close to Tell Brak $(8 \mathrm{~km}$

\begin{tabular}{|c|c|c|c|c|c|c|c|c|c|c|c|c|}
\hline $\begin{array}{c}\text { Av. J.-Ch. } \\
4800\end{array}$ & $\begin{array}{l}\text { Phase } \\
\text { Chronol. }\end{array}$ & $\begin{array}{c}\text { Habuba } \\
\text { Kabira }\end{array}$ & $\begin{array}{l}\text { Sheikh } \\
\text { Hassan }\end{array}$ & Arslantepe & $\begin{array}{c}\text { Hammam } \\
\text { et- } \\
\text { Turkeman }\end{array}$ & Norşuntepe & Brak & Tell Feres & Leilan & Hamoukar & Gawra & Ninive \\
\hline \multirow[t]{2}{*}{4700} & \multirow{3}{*}{$\begin{array}{c}\text { Obeid } \\
\text { Récent (4) }\end{array}$} & & & & IVC & IB & & & VIA & & XIV & hiatus \\
\hline & & & & & \multirow[t]{2}{*}{ IVD } & IC & CH 22 & 10 & \multirow[t]{2}{*}{ VIB } & \multirow{2}{*}{$\begin{array}{c}\text { Area Z } \\
5\end{array}$} & XIII & \multirow[t]{2}{*}{-64} \\
\hline \multirow{2}{*}{4500} & & & & & & $\|$ Ancien & & $9 \mathrm{~B}$ & & & XIIA & \\
\hline & LC1 & & & VIII & VA & $\begin{array}{c}\text { IIA récent } \\
\text { ॥B }\end{array}$ & $\begin{array}{c}\mathrm{CH} 20 \\
19\end{array}$ & $\begin{array}{l}9 \mathrm{~A} \\
8 \\
7\end{array}$ & \multirow{3}{*}{ hiatus } & $\begin{array}{c}\text { Area Z } \\
4\end{array}$ & XII & $\begin{array}{c}-60 \\
\text { (hiatus ?) }\end{array}$ \\
\hline \multirow{3}{*}{$\begin{array}{l}4200 \\
3900\end{array}$} & \multirow{2}{*}{ LC2 } & & & \multirow{4}{*}{ VII } & $\begin{array}{c}\text { VB } \\
\text { ancien }\end{array}$ & $\begin{array}{l}\text { IIC } \\
\text { IIIA }\end{array}$ & $\begin{array}{c}\mathrm{CH} 18 \\
17\end{array}$ & 6 & & \multirow{2}{*}{$\begin{array}{c}\text { Area Z } \\
3 \\
2 \\
1 \\
\text { hiatus }\end{array}$} & $\begin{array}{c}X I A-B \\
X_{I} \\
x_{a}\end{array}$ & $\begin{array}{l}\text { Gawra A } \\
-59 \\
50\end{array}$ \\
\hline & & & & & $\begin{array}{c}\text { VB } \\
\text { récent }\end{array}$ & IIB & $\begin{array}{c}\text { CH 17a } \\
\text { TW 22-21 } \\
\text { (20) }\end{array}$ & $\begin{array}{c}5 \\
4 B \\
4 A\end{array}$ & & & $\begin{array}{c}\mathrm{X} \\
\mathrm{IX} \\
\text { (VIII) }\end{array}$ & $\begin{array}{c}\text { Gawra B } \\
-50 \\
45\end{array}$ \\
\hline & LC3 & & $\begin{array}{l}13 \\
10 \\
\\
8\end{array}$ & & & & $\begin{array}{c}\text { TW 19-15 } \\
\text { CH 16-15 } \\
\text { HS1 Phase } \\
\text { F }\end{array}$ & $\begin{array}{l}3 \\
2 B \\
2 A\end{array}$ & v & Area B & & $\begin{array}{c}\text { NordUruk } \\
\text { A } \\
-45 \\
-37\end{array}$ \\
\hline 3600 & LC4 & & 7 & & & & $\begin{array}{l}\text { TW 14-13 } \\
\text { CH 14-13 } \\
\text { Phase F }\end{array}$ & $1 \mathrm{~B}$ & IV & & & $\begin{array}{c}\text { NordUruk } \\
\text { B } \\
-37 \\
-31\end{array}$ \\
\hline \multirow{2}{*}{3300} & 105 & the & 5 & Début & & & \begin{tabular}{|c|} 
TW 12 \\
Début Ph. G
\end{tabular} & $1 \mathrm{~A}$ & thetrot & & & Ninive IV \\
\hline & 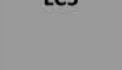 & 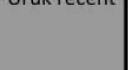 & 4 & VI & & & $\begin{array}{c}\text { TW 11-10 } \\
\text { Phase G }\end{array}$ & & matus & & & 20 \\
\hline
\end{tabular}

Figure 1: Comparative stratigraphic chart (@ Mission Tell Feres).

\footnotetext{
Cf. Stein, Alizadeh \& Rowan in press.

2 For example Tepe Gawra: Rothman 2002.
} 


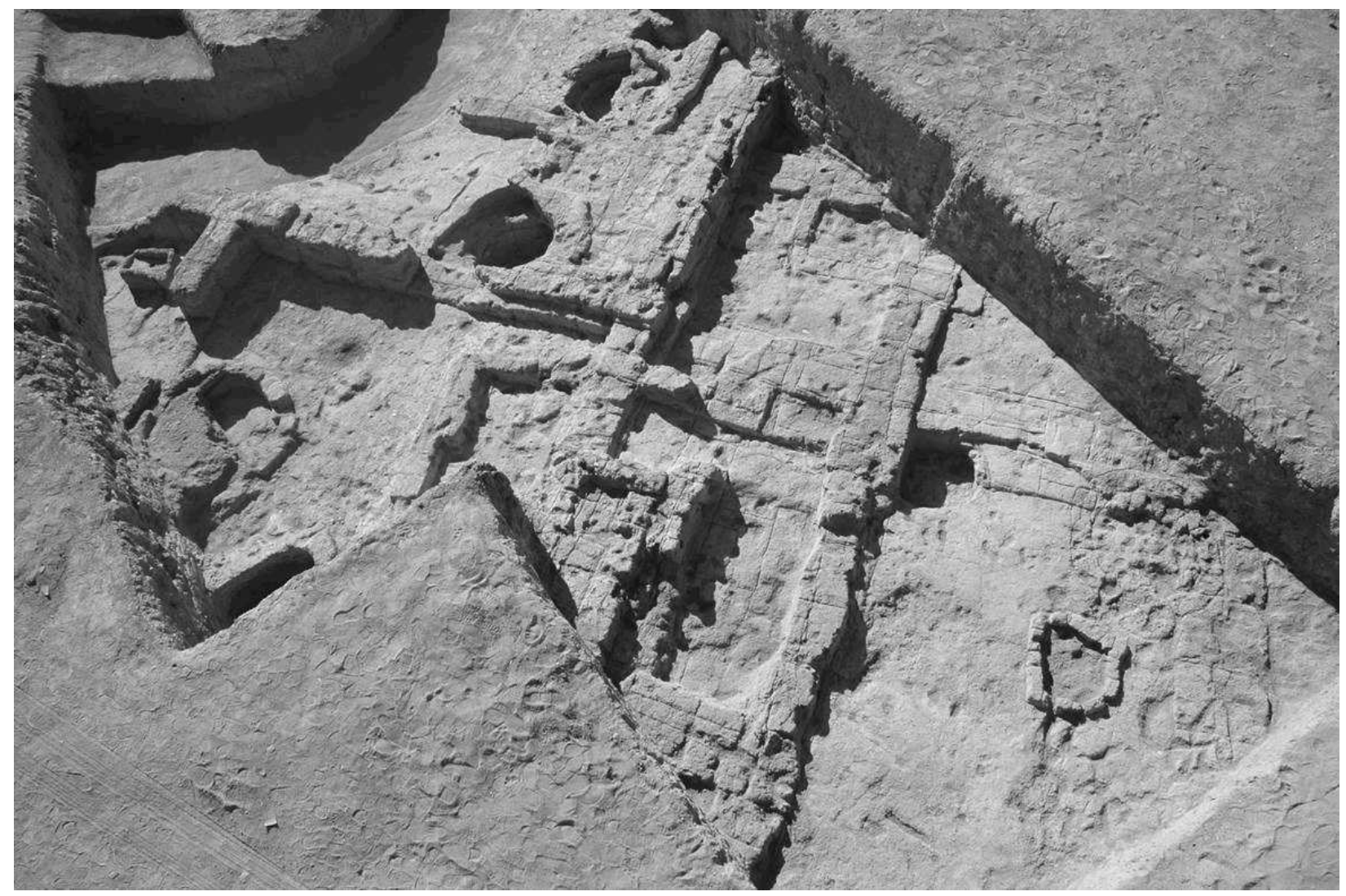

Figure 2: Ubaid pottery workshops of level 10, from the north ( Mission Tell Feres).

to the south), the site covers about 4 ha and reaches a height of $7 \mathrm{~m}$ above the surrounding plain. It was chosen because 5th and 4th millennia layers were accessible on the surface. The excavations were located on the summit and the northern slope of the tell and uncovered about $900 \mathrm{sq} . \mathrm{m}$. Ten main levels have been distinguished (Fig. 1) over a depth of $5 \mathrm{~m}$, ranging from late Ubaid (mid-5th millennium) to Late Chalcolithic 5 (3300-3000 BC).

The deepest level reached, about $2 \mathrm{~m}$ above the plain at the foot of the tell, is Ubaid (level 10). In 2009, a multi-room building containing a kiln, some tools and over-fired sherds, suggesting a pottery workshop, was discovered. During our last season in 2010 these remains were one of our main goals, but what we found surpassed our expectations. We cleared about $60 \mathrm{sq} . \mathrm{m}$ and realized that we were dealing with no less than four workshops, symmetrically arranged within the same building: a fifth millennium factory for making pottery (Fig. 2). Each production unit was provided with two kilns, a tank for the preparation of the clay and benches for the drying of the vessels. Dozens of clay samples with the fingerprints of the pottery makers were found on the floor of the building (Fig. 3). One is particularly surprised to see such a degree of specialization and above all production organization during the Ubaid. Also, the building continues in all directions, and may include more units. Each unit has specific features, for example different types of kilns, but more importantly each one was producing the same complete set of the Ubaid assemblage, but using different techniques. Besides the usual morpho-stylistic study, all the pottery of the site has been examined from a technological point of view, not only the identification of the key paste/ware types but also microscopic observation of the "chaîne opératoire" through which the wares and forms were produced. ${ }^{3}$ It appears that at the end of the Ubaid, five different technical traditions ("Groupes Techniques", or "GT") existed at Tell Feres, sharing at first their pastes (level 10B: the workshops communicate through passageways), which is not the case later on (level 10A: the workshops are rebuilt isolated from one another). This provides conclusive evidence that pottery production was taken up by

3 For a complete and thorough study of the Ubaid, LC1 and LC2 pottery, see BALDI 2015. 


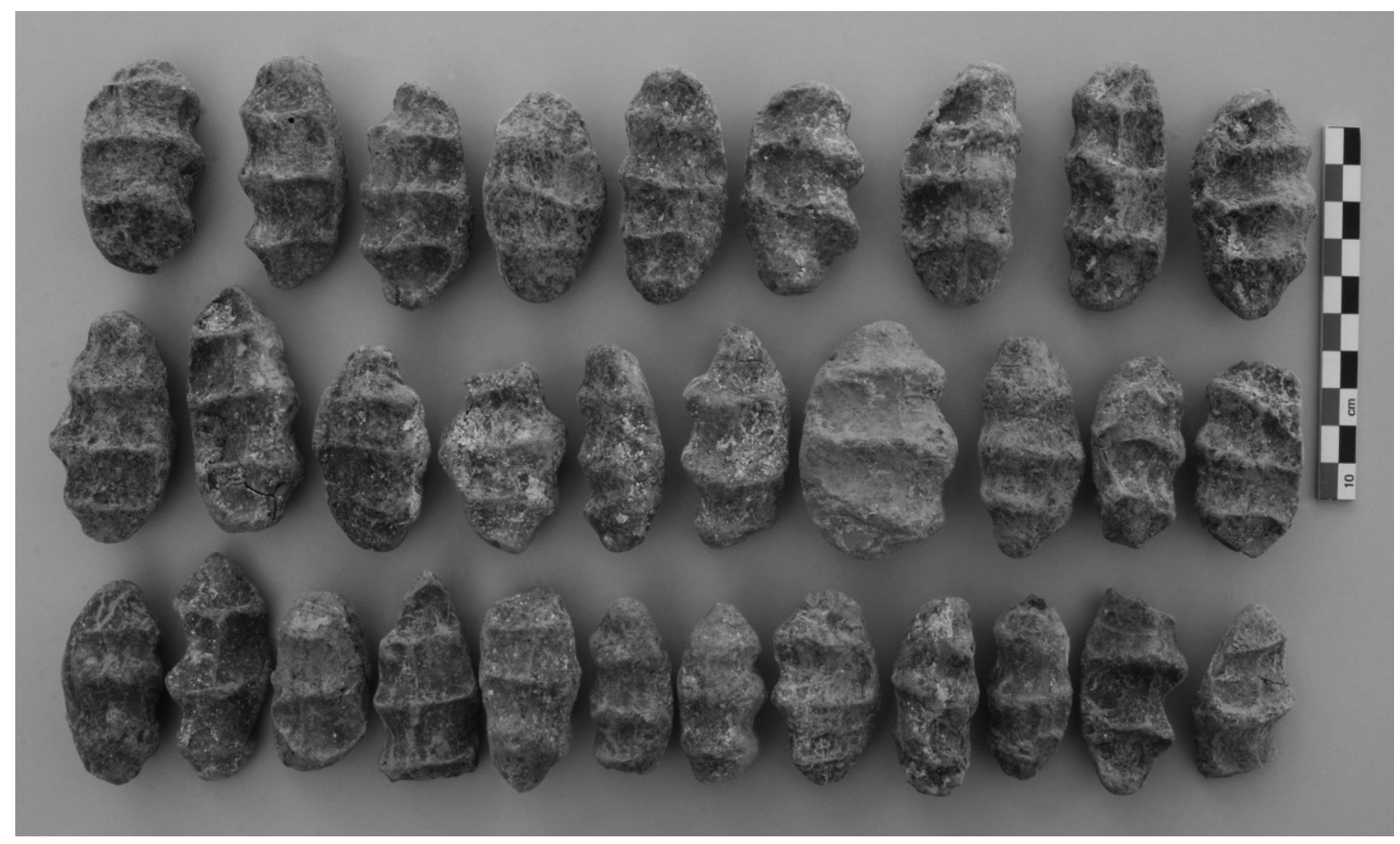

Figure 3: Clay samples from level 10 (@ Mission Tell Feres).

several distinct social groups, based most probably on kinship, i.e. a lineage-based ceramic production. Furthermore, the painted motive repertoire differs between the different technical traditions/groups recognized. Thanks to the stratigraphic and extensive approach followed by the excavations, we were also able to follow through time and space the distribution and evolution of the assemblage, and to observe the dramatic drop of its technical diversity: of the five groups identified at the end of the Ubaid (displaying 28 different techniques altogether, once taken into account the pastes used) only two remained at the end of the LC2 (and 5 techniques only, plus the appearance of the wheel-finishing during the LC2 period). Here one can see, and even measure, the development of full-time specialization, i.e. professionalization, in the pottery industry, the small number of remaining producers having to satisfy an ever increasing demand. Most of this process is achieved at the end of the LC2, and it clearly explains the progressive disappearance of painting (Late Ubaid: $20 \%$ of painted pottery, LC1: 8.3\%, LC2: 1.4\%). In addition to that, the spatial distribution of the pottery within the settlement showed an unexpected and almost perfect coincidence between the architecture and the existing technical traditions/groups (with concentrations of about $98 \%$ per building), revealing that at the end of the Ubaid people were using the pottery produced by and within their own community, and this reality continues through time (the pottery produced by different technical traditions is never mingled - with one exception, see below) despite the decreasing number of the producers, allowing us to identify in the actual space of the site the different components of its population. But it is also quite clear that the "factory" of level 10 seems oversized compared to the site, and played a role on a regional, or micro-regional, scale. In fact, the presence of such a building at Tell Feres suggests that the site was of some importance before the rise of Brak, and the finds from the next level point in the same direction.

Since the first season in 2006 we know that the following level 9 (9B and 9A, respectively Ubaid and LC1 in date), contains some exceptional remains (Fig. 4). Until 2009 we thought that we were dealing with two buildings, apparently the same size and perfectly aligned, separated by a $2 \mathrm{~m}$ wide alley: Great Building 1 (GB1) to the west and GB3 to the east, both surrounded by a deep ditch into which rainwater was drained off through shallow gutters covered with sherds. Subsequently GB1 was replaced by a later building, GB2, extended further south but also further east over the old alley. That conception was wrong. Continuing 


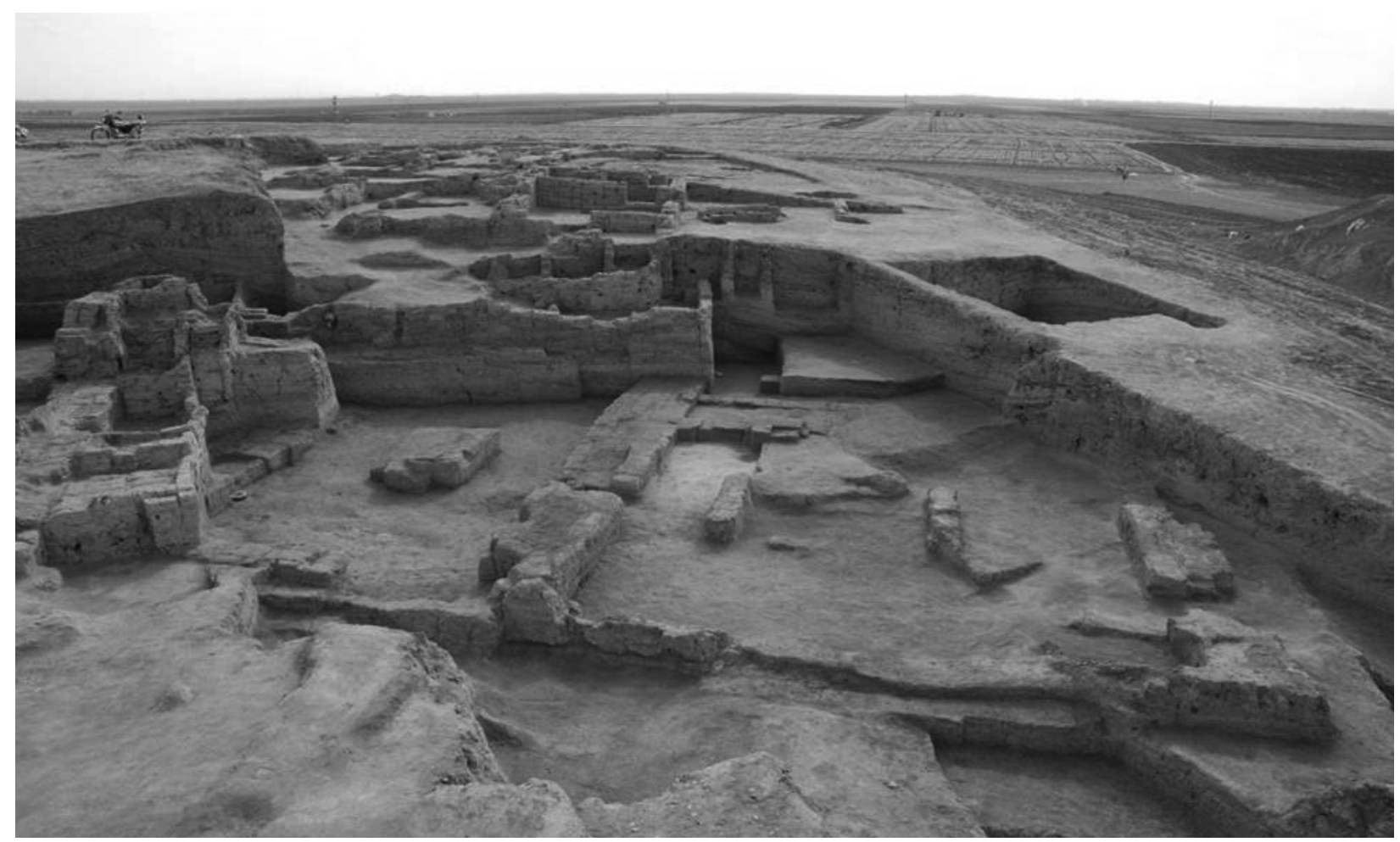

Figure 4: Great Building of level 9, from the north (@ Mission Tell Feres).

the excavations in 2010, below the floors of GB2 and further south, we realized that we had in fact just one large compound, covering perhaps $250 \mathrm{sq} \mathrm{m}$ (Fig. 5). To the east, the so-called GB3 appears to be a great hall, situated at the front of the building (Room 9). We do not know if one entered directly into this hall or through some vestibule (as suggested by late floors extending through the passageway east of Room 9), but in any case the main entrances of the compound were there. To the west, at the back of the compound, two rows of three rooms are arranged on each side of a perpendicular room $\left(n^{\circ} 4\right)$. We identified several doorways in the building, arranged in a linear fashion and intensively used (at least between the main hall and the north-west quarter, as shown by the floors), but closed by doors isolating the areas from one another. In a second phase (level 9A), the north-west quarter of the compound, and only that part, is rebuilt (our so-called GB2) and extended to the south over the Room 4, with a staircase to the south (Fig. 6). Roughly the same plan is maintained, with three parallel rooms. The passageway from the main hall was blocked and one has to go through room 8 , to the south, to gain access to the north-west quarter. Except for a large fireplace in the main hall, there were no other features and the building (9B and 9A) contained no finds other than sherds, but these gave us, as well as the plan itself, some clues concerning its functions. The pilastered front hall (Room 9) contained mainly Coba bowls, and there is no doubt that it was some kind of a meeting hall for the settlement. The north-west quarter and its long parallel rooms (Rooms 1, 2 and 3) contained mainly jars, of several types (holemouth, flaring rim, "urns" and S shape jars) and was clearly dedicated to storage. The south-west quarter with the large Room 4 and its associated rooms ( $\left.n^{\circ} 5-8\right)$, displayed a functionally much more diverse assemblage, as one would find in an ordinary dwelling, and that part of the building seemed to have been the private quarter of the people living there. To our knowledge, this building, grouping behind a ditch in a regular fashion residential, storing and public meeting areas, still has no strict formal equivalent (even if parallels may be drawn with Gawra XII and its "white room"), and for that reason is a good example of cultural variation inside Late Chalcolithic northern Mesopotamia. Furthermore, the Great Building of level 9, alone of the whole sequence, contained and mingled pottery vessels of three different technical traditions (GT3, 4 and 5), especially in its storage rooms, indicating that the elite began to drain and concentrate local resources, a trend that developed rapidly as shown by the extension of the storage instead of the residential area, restricted to an upper floor in level 9A (above the north-west quarter, hence the long staircase 4'). In 


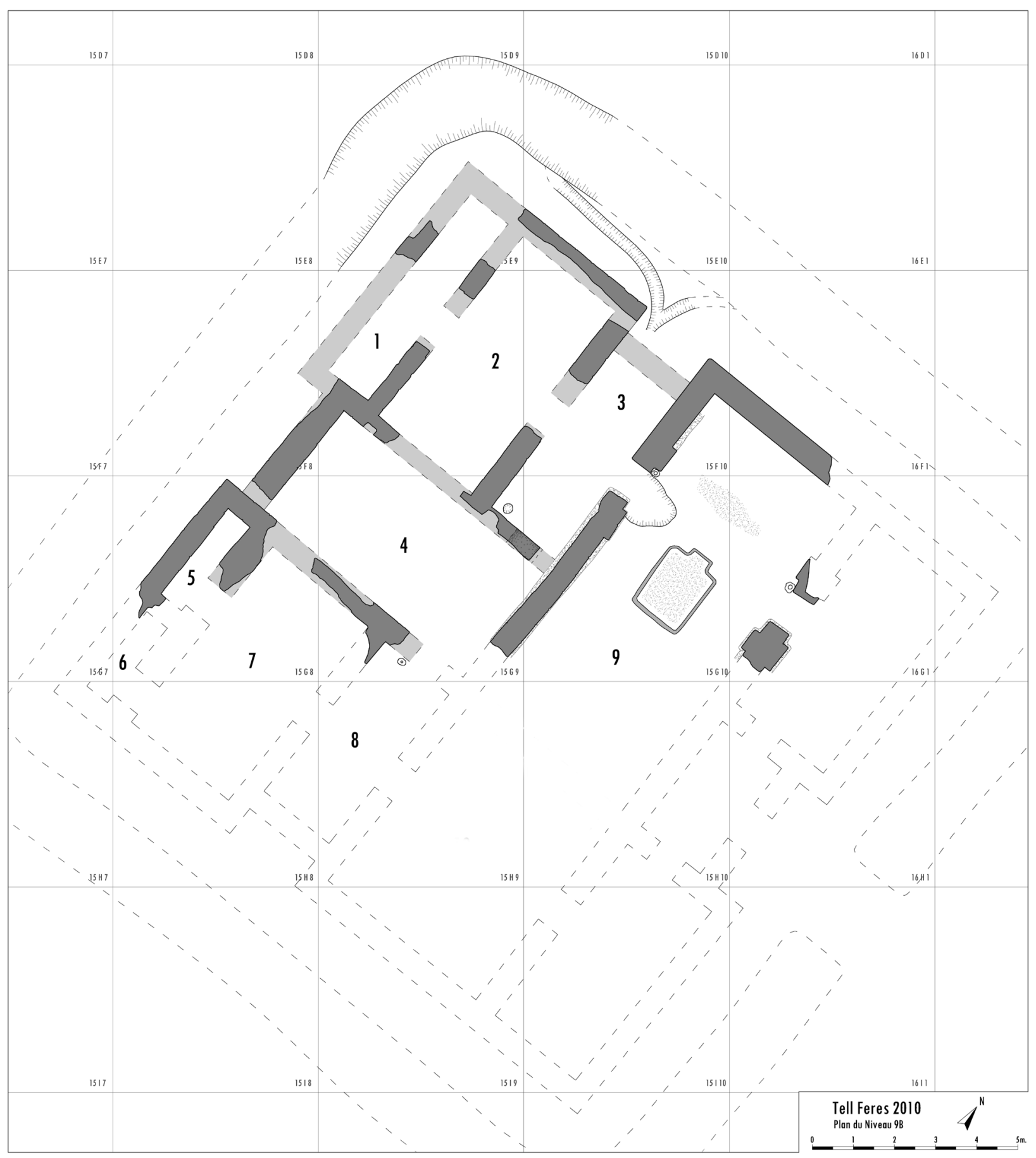

Figure 5: Plan of level 9B (late Ubaid) (๔ Mission Tell Feres).

any case, the presence of a building like this suggests that the site had some demographic and political importance during the LC1 period.

Later on, some potters returned, settled in the ruins of the compound and built two kilns (level 8) that were not physically connected to a workshop. The place is now exclusively dedicated to firing, and this constitutes another step in the specialization process of the pottery industry, one that could explain the appearance of the so-called potter's marks (which rather could have been "firer's marks" - it has also to be noted that the four GT remaining at that time were associated two by two to the kilns). In level 7, granaries (four of which have been discovered so far) finally cover the ruins of the building (Fig. 7). As mentioned above for all other buildings (except GB of level 9), each of them contained pottery of a 


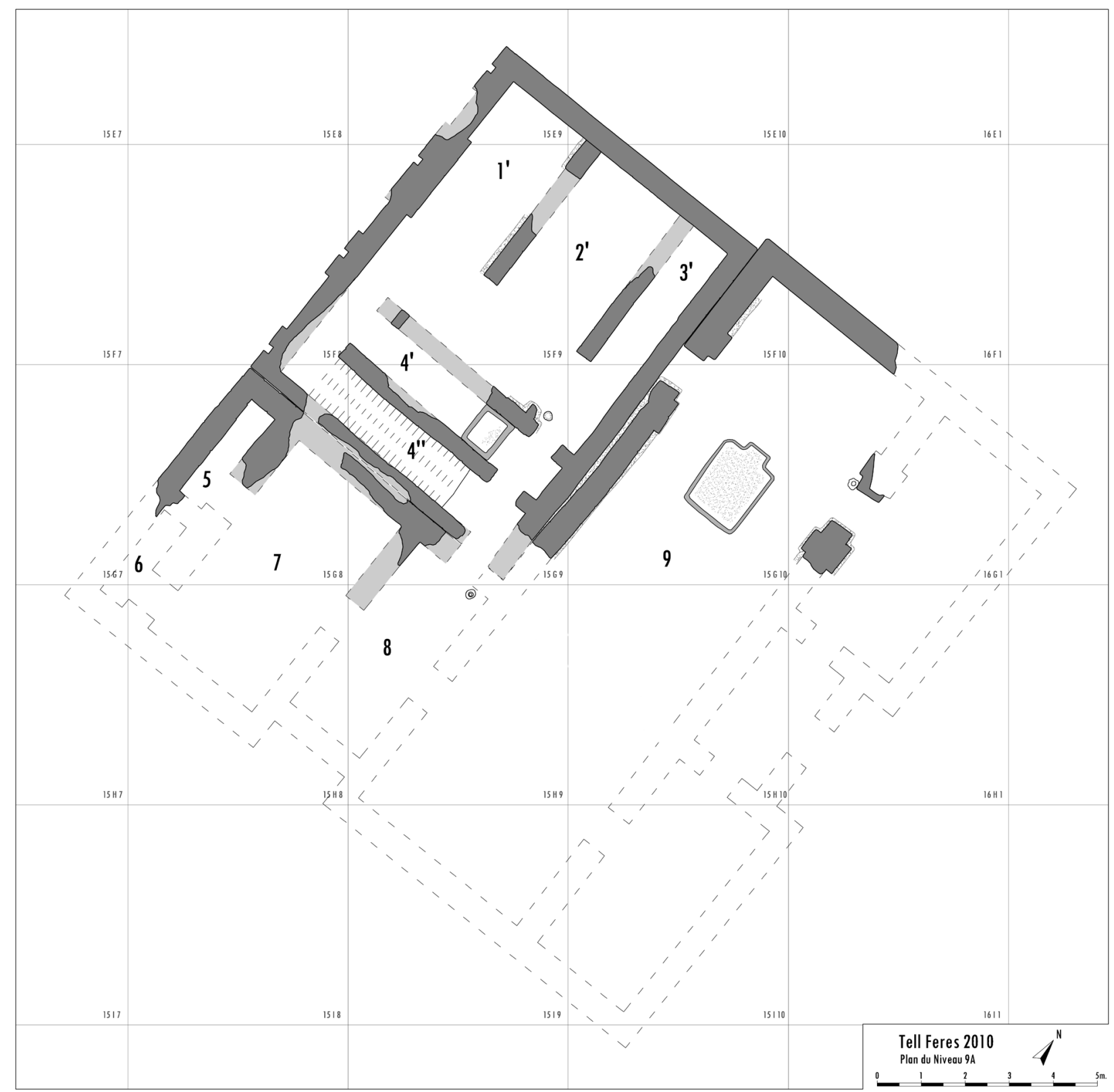

Figure 6: Plan of level 9A (LC1) (@ Mission Tell Feres).

different GT, clearly showing that if storage was concentrated in the same part of the site, it remained managed by several lineage-based authorities. The diversity of the conservation techniques also has to be pointed out. To the east, one storage feature was made of small squared cells provided with carefully laid and thickly plastered mudbrick floors, showing that the goods were kept on the ground. Another Level 7 granary, in the centre of the trench, was originally a long two-roomed building (14 sq.m.), the basement of which was interrupted by narrow openings for ventilation. Above was a platform on which the grain was kept. It seems that buildings of this kind were regularly cleaned by fire, for large amounts of ash and charred grain accumulated in the area. Botanical remains have been extensively sampled, throughout all the levels. The analyses are not yet completed, by M. Tengberg (MNHN, Paris), but we already know 


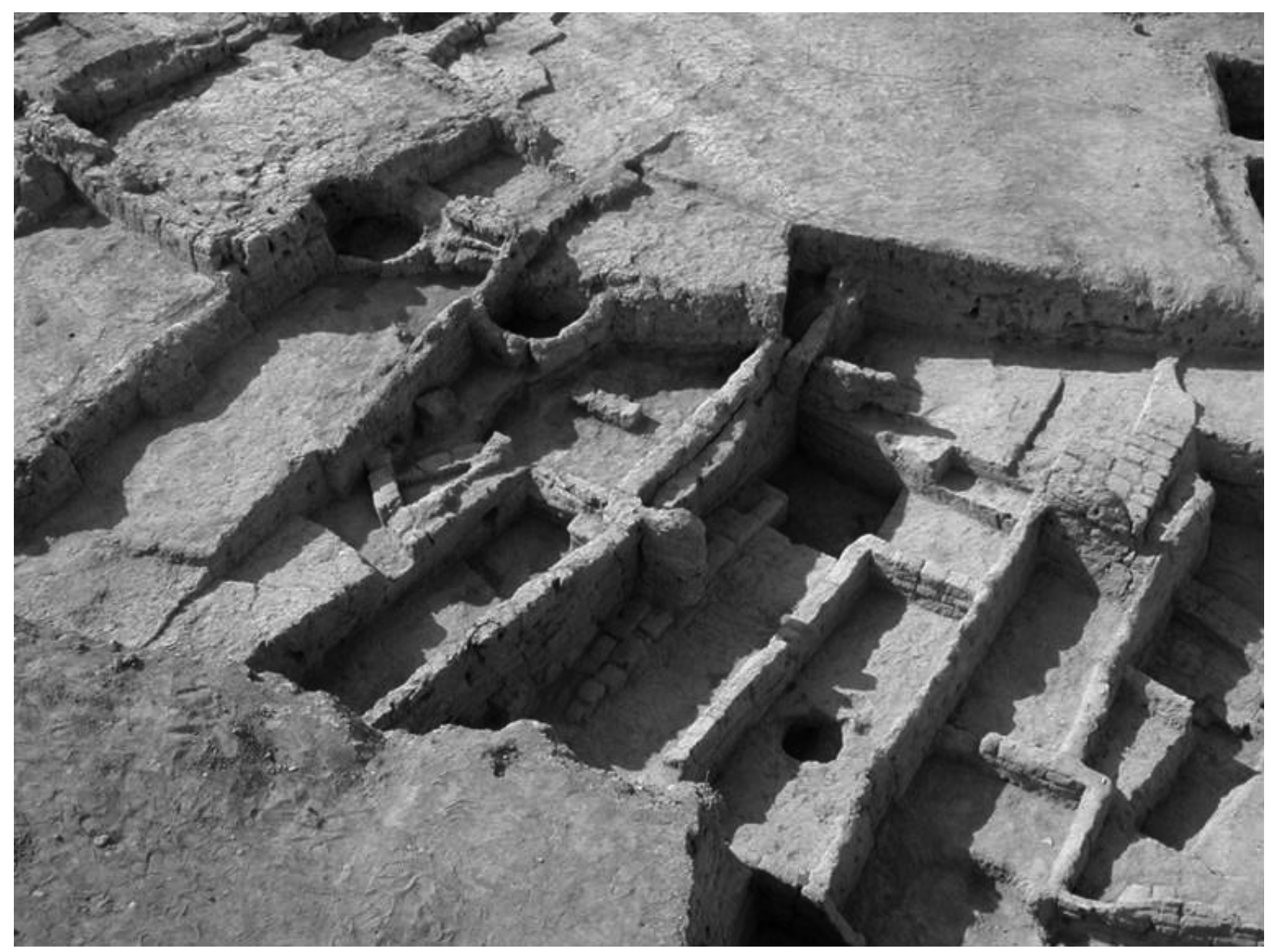

Figure 7: Granaries of level 7 (LC1), from the west (๔ Mission Tell Feres).

that the most common plants are cereals (barley and emmer wheat) and pulses. Faunal remains, studied by E. Vila (CNRS, Lyon), are mainly of domestic animals (sheep, goat, pig, cattle - with a rise of cattle at the LC5 period), but there is also evidence for hunting (hare, gazelle, equids, aurochs, birds - less than $10 \%$ altogether). Twenty-three radiocarbon dates have been obtained on samples of charcoal and grain, throughout the whole sequence, but only nine of them are consistent with the stratigraphy, although a little older than expected (Poznan dates calibrated with OxCal v. 4.1.5):

Level 9B (Late Ubaid): Poz-46945: 4723-4532 (95.4\%), 4690-4584 (68.2\%) cal. BC

Level 9B (Late Ubaid): Lyon-6095: 4721-4546 (95\%) cal. BC

Level 9A (LC1): Poz-46944: 4778-4496 (95.4\%), 4702-4552 (68.2\%) cal. BC

Level 9A (LC1): Poz-49947: 4703-4500 (95.4\%), 4619-4545 (68.2\%) cal. BC

Level 8 (LC1): Lyon-6093: 4718-4543 (95\%) cal. BC

Level 7 (LC1): Lyon-6092: 4513-4353 (95\%) cal. BC

Level 6 (LC2): Lyon-6091: 4457-4343 (95\%) cal. BC

Level 2B1 (LC3): Lyon-6094: 3701-3630 (95\%) cal. BC

Level 1C (LC4): Poz-46930: 3580-3534 (95.4\%) cal. BC

The fourteen other samples form two groups that produce roughly the same date, whatever the stratigraphic location of the sample, so it seems obvious that they were subject to some pollution within the tell itself, a situation that could have resulted from catastrophic floods that inundated the whole surrounding plain, a phenomenon recorded by several layers in the stratigraphy. According to the available radiocarbon dates, it seems that the LC1 assemblages appear at Tell Feres around 4600/4550 BC. 


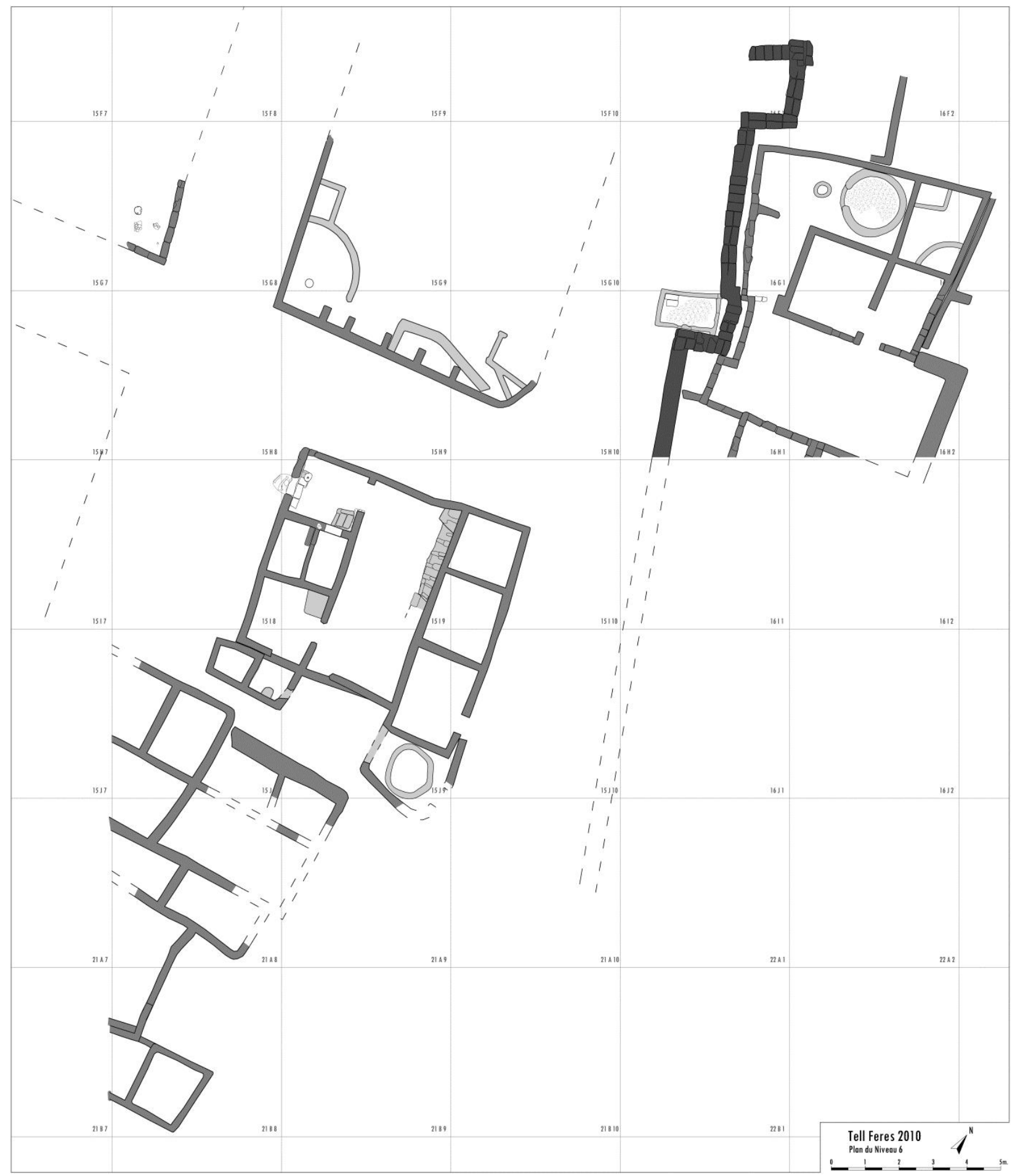

Figure 8: Plan of level 6 (LC2) ( Mission Tell Feres).

Level 6, a little higher up the slope, has been completely cleared at the top of the tell, after removal of all the subsequent levels (in particular level 2, see below), and is the most extensively known occupation phase, giving us a glimpse of the layout of the site at the beginning of the LC2 period (Fig. 8). We had already identified in 2009 a trapezoidal workshop to the north-east with a huge oven, and parts of an enclosure to the north with different types of storage features inside (Fig. 9). In 2010 we discovered a tripartite house just south of this enclosure. The house is quite small, $7.2 \mathrm{~m}$ long and $7.3 \mathrm{~m}$ wide, and shows a classic tripartite plan with three side-rooms on either side of a central room. Only the vestibule, to the north-west, and a 


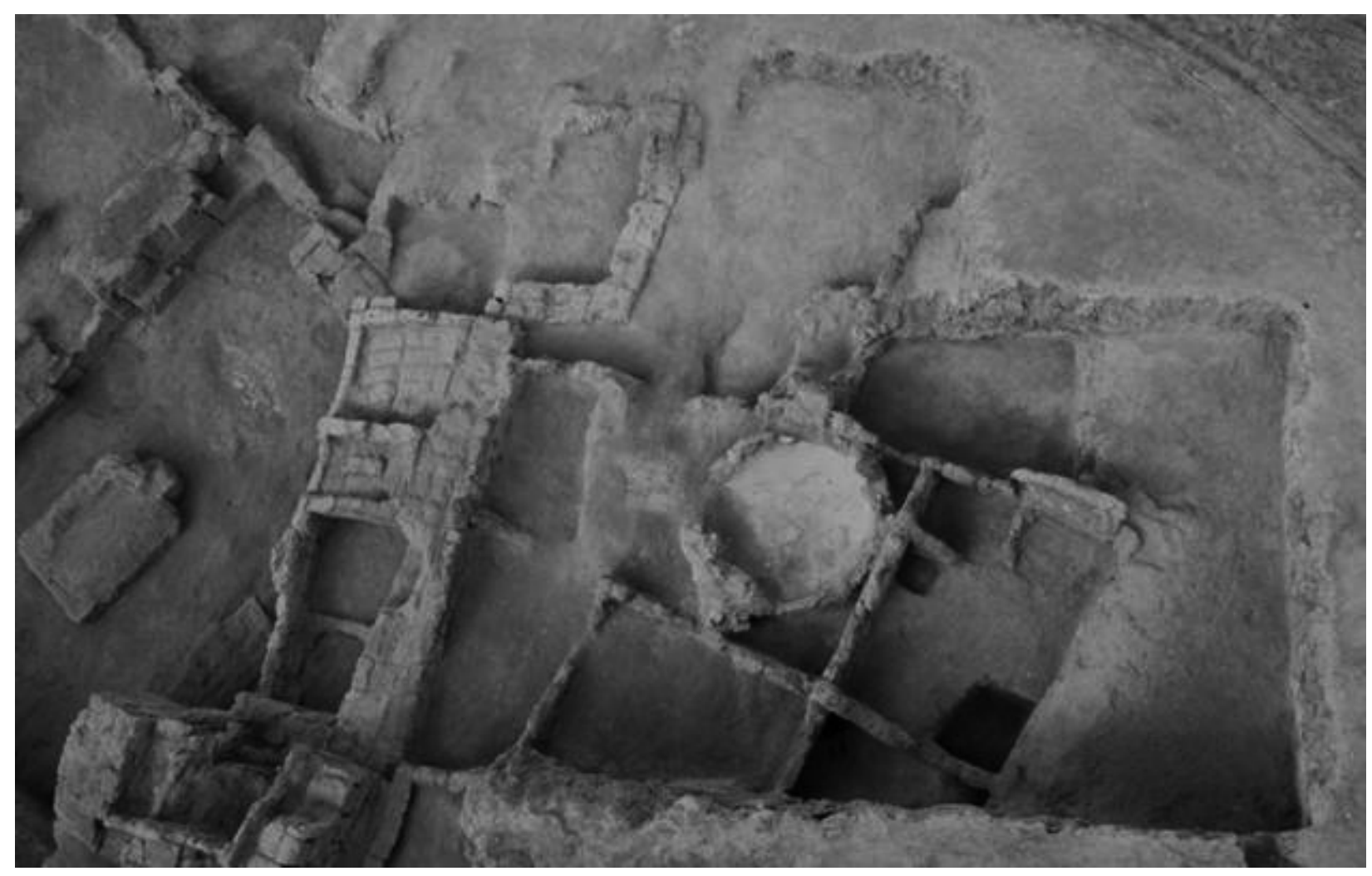

Figure 9: Level 6, partial view ( Mission Tell Feres).

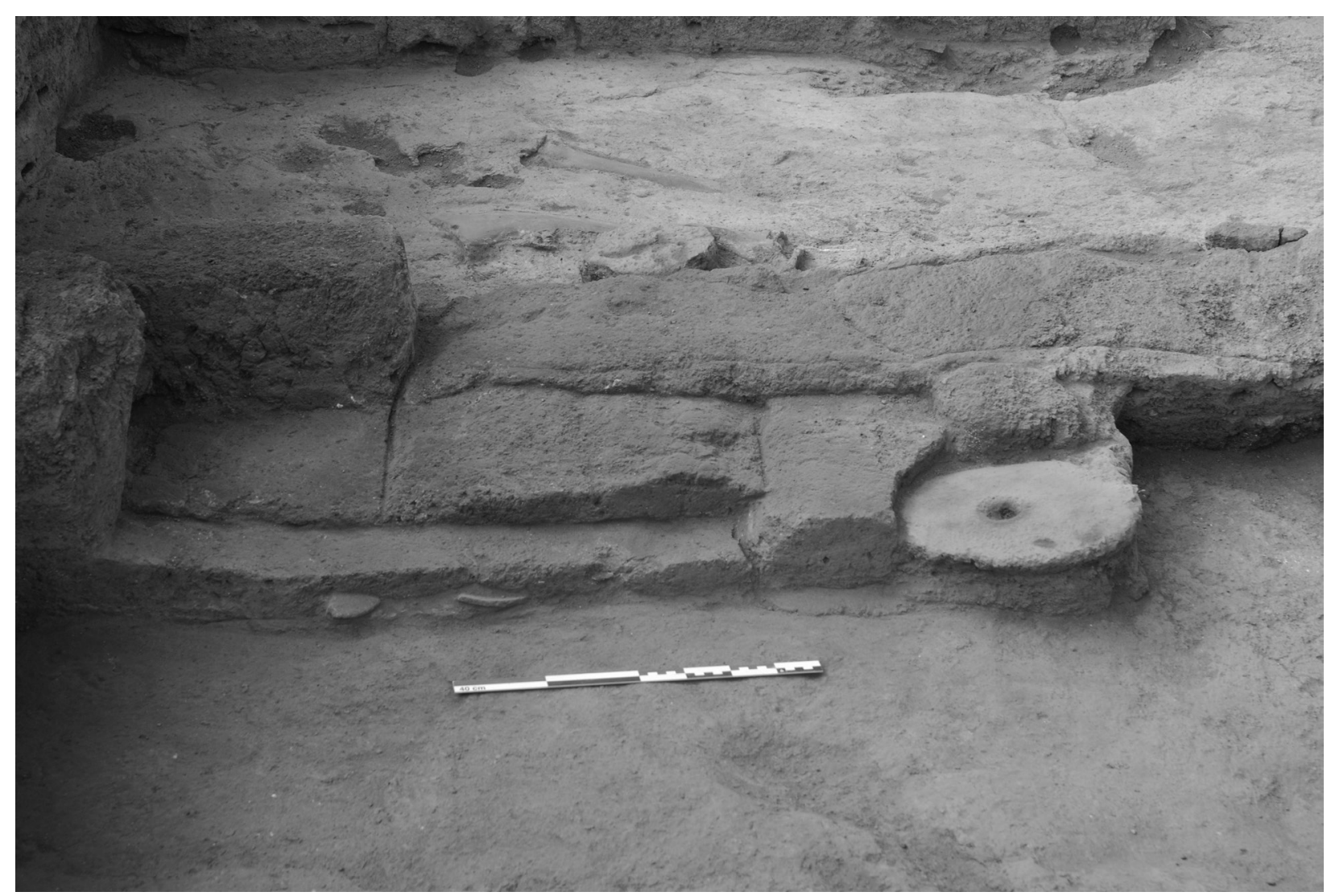

Figure 10: Level 6, main entrance of the tripartite building, from the inside (๔ Mission Tell Feres). 
small part of the central room has been excavated down to the floors. Outside the building, against the threshold of the entrance ( $0.55 \mathrm{~m}$ wide, equipped with a door-socket), a shallow pit contained a propitiatory foundation deposit, with a cattle mandible and long bone (Fig. 10). Surprisingly, the building has thin walls, made from a single row of mud-brick. The main room has a podium in its north-east corner and a rather unusual storage feature along its eastern wall: a long row of small mud-brick boxes. To the south, the house was flanked by two small silos to the west and by an external kitchen, with a large oven, to the east. On the other side of a small alley to the south, several smaller constructions began to appear at the summit of the site, showing that it was densely built. But the most unexpected feature of this phase is its regular layout: all the constructions are laid out orthogonally, with wide streets $(3.5 \mathrm{~m})$ crisscrossing at right angles, with a small area kept free in front of the house. In addition, the core of the settlement was surrounded by a wall (in dark grey on the plan). This was not a defensive wall, as it is too small and narrow for any serious defensive purpose. Its function seems to have been different: one observes that the workshops are outside, storage and housing inside. Perhaps the wall also had a social or political function, isolating a specific area of the settlement. In any case, this example of proto-urban planning at the end of the fifth millennium implies, as mentioned for the previous levels, that the site must have been of some importance to require this kind of organization, with a central authority to put it into effect.

After some time (level 6 contains three sub-phases), the area is completely cleared of all its constructions, replaced by a new public building, surrounded by underground silos (of which three have been discovered). This level 5, once a major goal of the excavations, proved to be very partially preserved. The building has a recessed façade set just on top of the northern slope of the tell, and was probably visible from afar in the countryside. Its plan appears very simple, with a main room ( $5.5 \mathrm{~m}$ wide), flanked by at least two small annexes to the west and a porch (or a vestibule) to the south, where we found one of the entrances to the main room (provided with a threshold and a door-socket). It contained nothing but sherds. These proved to belong to the same group (GT5) as the pottery coming from the domestic sector of its level 9 predecessor, four centuries earlier. But this building did not last very long, and was replaced by communal granaries. Until 2010, we thought that the site, or at least the highest part of it, was abandoned after level 5 and that there was a gap in the stratigraphy at the transition between LC2 and LC3. We were wrong. During our last season, the removal of later remains at the top of the tell revealed two unexpected late LC2 levels (4A and $4 \mathrm{~B})$ as well as the internal structure of the ancient tell: the eastern slope of the late LC2 site is right in the middle of the present tell, which means that all its eastern part belongs to the LC3 and later periods. In addition, examination of the pottery sequence enabled us to re-date level 2 to late LC3 rather than LC4 (a date also more in accordance with the $\mathrm{C} 14$ that we already have for that level, see above). So, it appears that the LC3 occupation of the site is more important than we thought, and in any case there is no gap at all in the stratigraphy. Level $4 \mathrm{~B}$ contains communal storages facilities arranged in an Umm Dabaghiyah-like fashion, ${ }^{4}$ with linear small cells like the eastern storage of level 7. Level 4A has a series of cooking ovens, one of which gave a nice sealing (Fig. 11) of a Gawra X

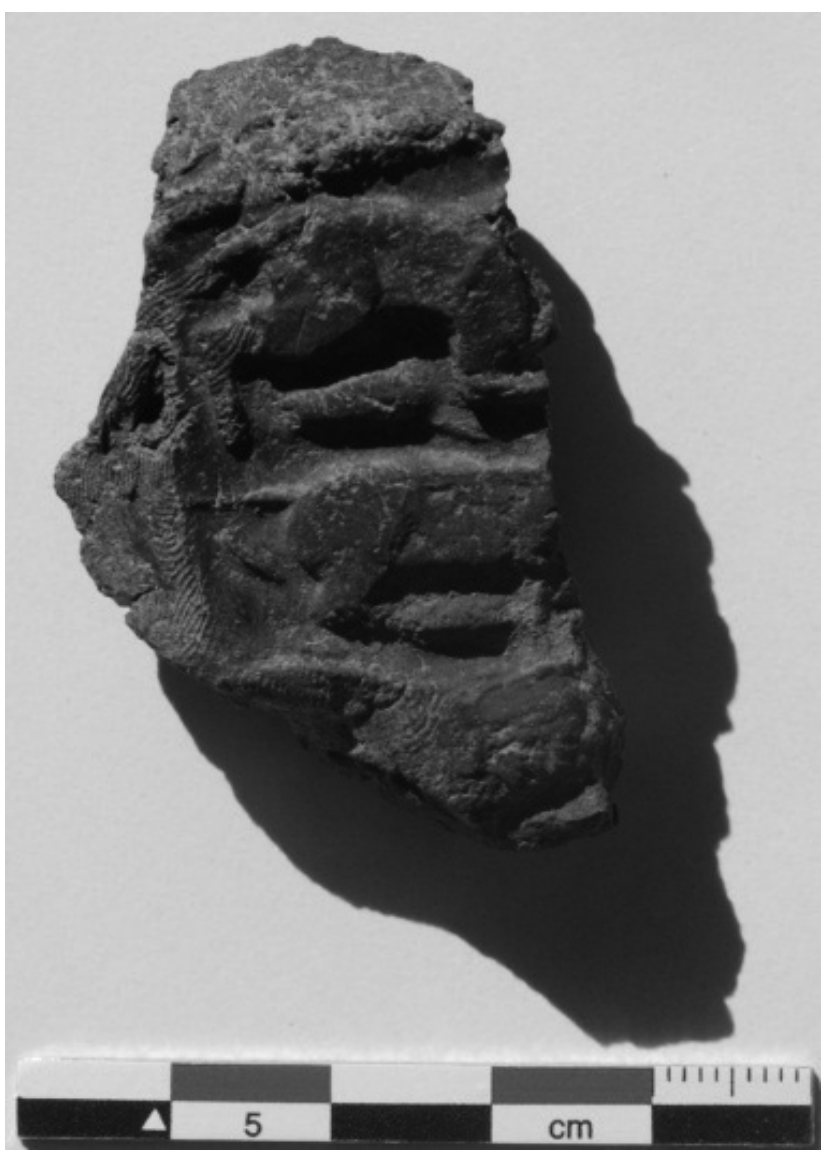

Figure 11: Sealing from level 4A (late LC2) (๔ Mission Tell Feres). 
type. ${ }^{5}$ The site delivered an appreciable amount of small finds including, in all levels, grinding stones, an abundant lithic industry dominated by obsidian (mainly coming from Bingol A and Nemrut Dag, but also Aragat in Armenia, according to B. Gratuze and S. Boucetta, CNRS, Orléans), and dark stone tools: axes, adzes or wood chisels, a few hammers. The bone industry is mainly represented by points. Terracotta objects include spindle whorls, animal figurines and "spectacle idols," from LC2 but also LC1 levels (Fig. 12), i.e. the earliest objects of this type known at present (which is especially interesting from an iconographic point of view as it makes a link between the large "eye" painted motives of the Ubaid and the later 4th millennium "eye figurines"). Fragments of stone vessels were found, as well as many personal ornaments: beads made in various materials (including carnelian, obsidian and turquoise) and pendants with incised decoration. There were also hemispheric stamp seals and clay sealings with a geometric or naturalistic decoration (Fig. 13).

In Level 3, early LC3, another granary is built more to the east, above the thick ashy layers produced by the ovens, and in Level

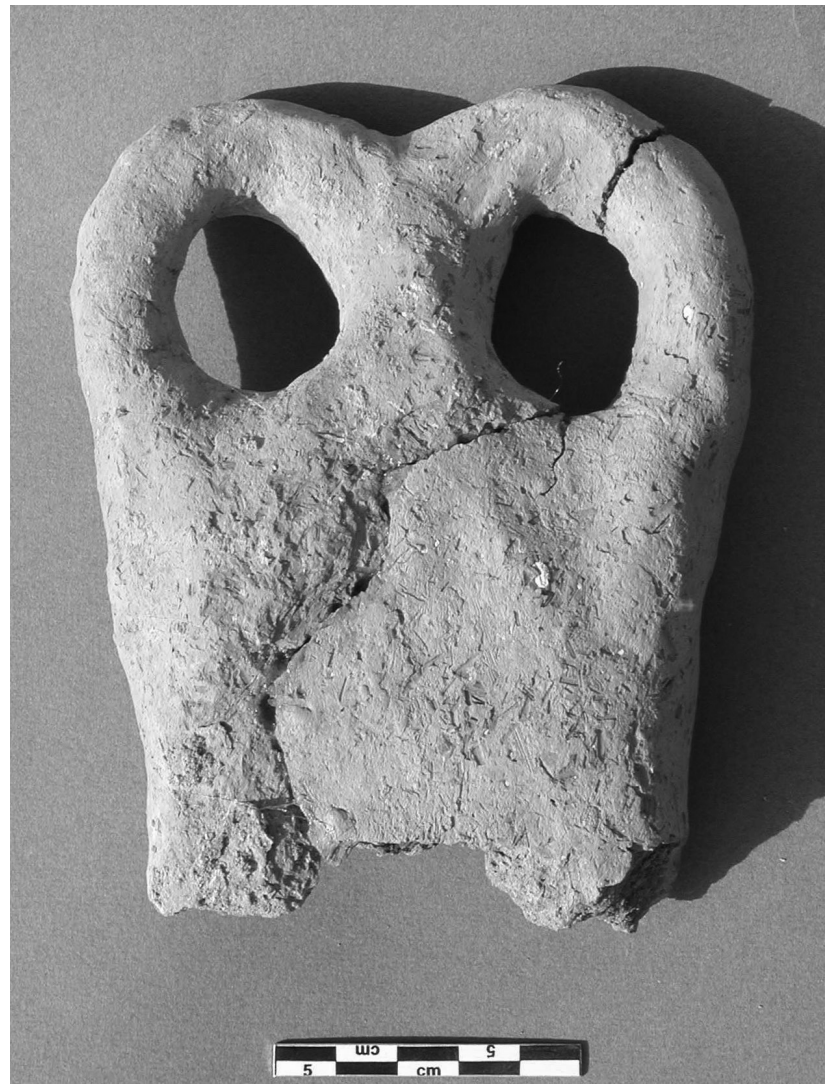

Figure 12: "Spectacle idol" from level 7 (LC1) (@ Mission Tell Feres). 2 the whole area is covered by a large house compound. In 2009 we found its southern façade and the main entrance, to the south-east. In 2010, we hoped to find remains of its western wing. We did, but all that the erosion had left was the corner of a large room. So, the excavation of level 2 was finally completed, the only operation that we had time to finish. Apart from the tripartite house to the north-west, this level was poorly preserved, with just one or two (sometimes less) layers of mud-brick, cut through by more than seventy later pits and graves. It is a miracle that we were able to excavate that building. But another miracle is that the erosion has left just enough of it for us to understand and reconstruct its plan (Fig. 14-15). This rectangular compound covered an area of about $425 \mathrm{sq} \mathrm{m},(25 \mathrm{~m}$ from north to south and $17 \mathrm{~m}$ from east to west). Its plan integrates an almost Ubaid-like tripartite house into a well-planned compound suggestive of those of the end of the millennium (Habuba Kabira, Djebel Aruda, Hassek Höyük). ${ }^{6}$ As in Uruk compounds, the western large room could have been a reception room. In the tripartite house, we were able to follow change in the internal layout, especially with the location of the kitchen, that shifted through time from the main room $\left(n^{\circ} 11\right)$ to a side room $\left(n^{\circ} 8\right)$ and vice versa, showing that this was still an issue in domestic life. Most of the other rooms of the compound were used for storage, and it is clear that the storage needs surpassed by far the household level, as indicated also by the increase in jar size. If we are dealing here with a large farm, it was now producing also for the nearby city of Tell Brak which had just reached urban size at that time. ${ }^{7}$ In a few centuries, society had completely changed, and domestic architecture reflects that change in a particularly striking way, if one recalls the level 6 house, just below. Also, one can note that there is no difference between the houses of the rural sites like Feres and the first proto-urban sites, as Hamoukar with very similar compounds shows. ${ }^{8}$ This is not really surprising: the formation of a truly urban domestic architecture will take some more

\footnotetext{
5 Cf. Rothman 2002, pl. 53:1980 and 2030.

6 VAllet 1997a, 1997b, 1998; Forest \& VAllet 2008a.

OATEs 2002; OATES et al. 2007; Wright et al. 2007; MCMAhon 2007.

8 ReICHEL 2011.
} 


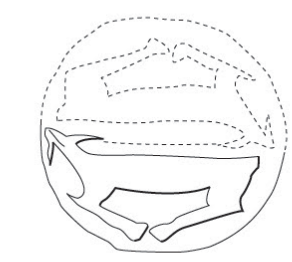

99.2
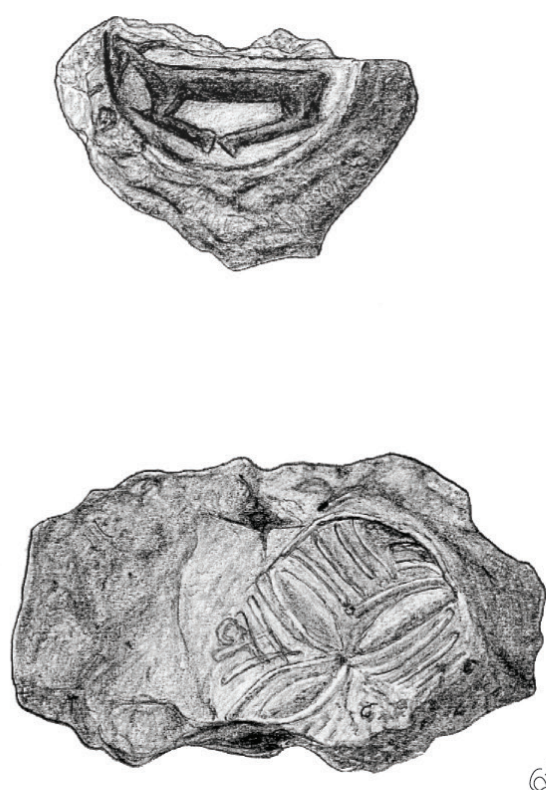

409.2
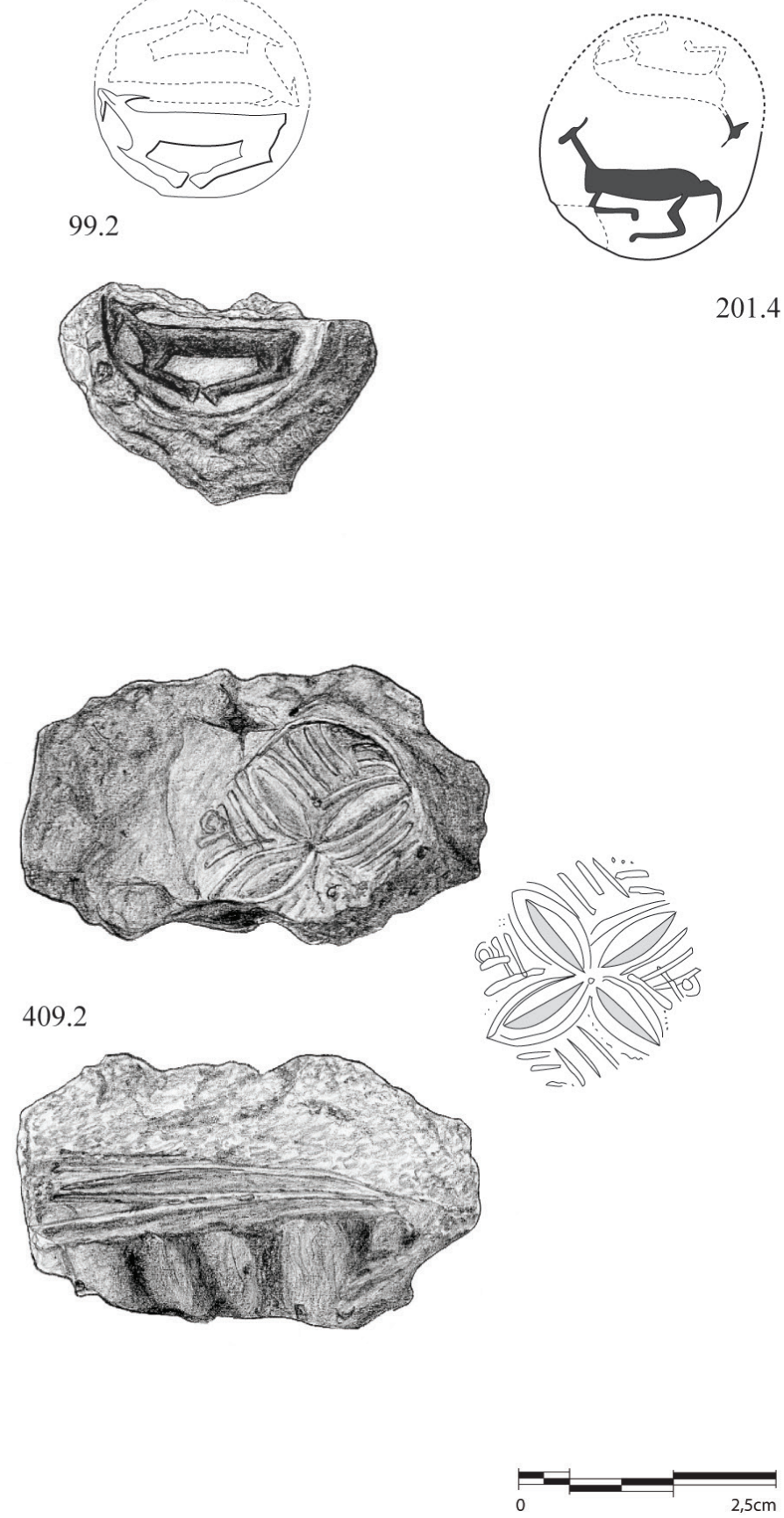
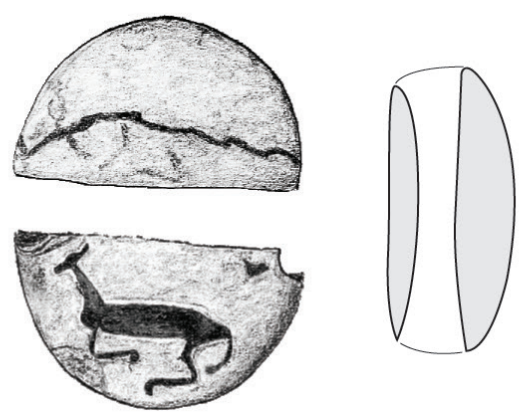

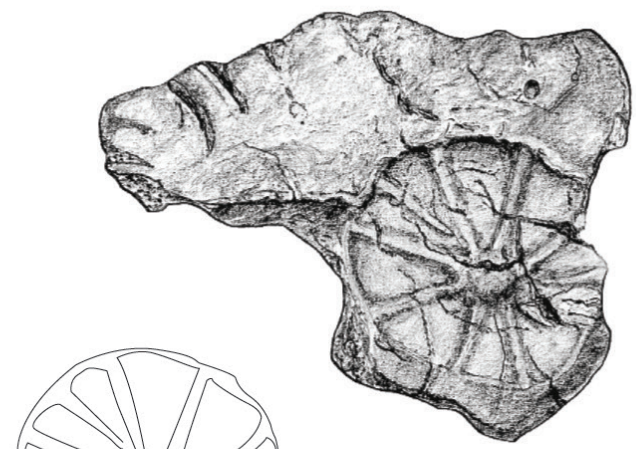

313.2
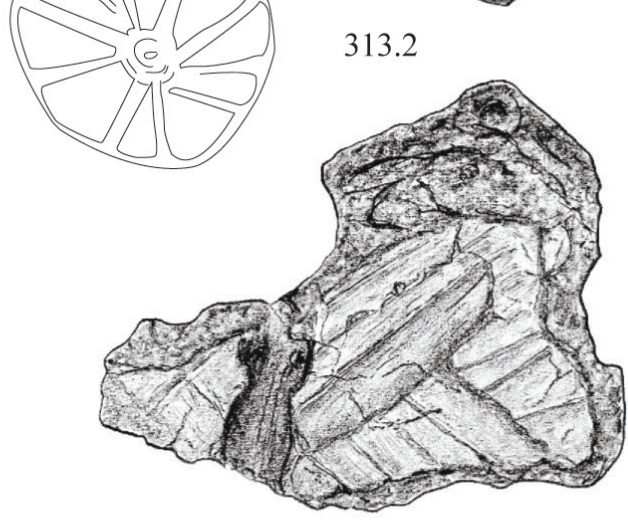

Figure 13: LC1 (409.2), LC2 (201.4 and 313.2) and LC3 (99.2) seals and sealings (๔ Mission Tell Feres).

centuries. ${ }^{9}$ But the owner of this compound was probably of a high social status, and certainly not the least of the village. This is reflected by several facts: the location of the building on top of the site, where the public buildings had previously stood, its size and regular layout, but also, beside a small number of seals and sealings, a marble mace-head found on a floor of the building (Fig. 16). One final observation should be noted. The late compound (2A) contains the mud-brick coffin of a child (Fig. 17), that had been looted and partly destroyed soon after the abandonment of the building (the looted tomb was covered by LC4 layers of level 1C), but the site continues to be occupied for a while. One can hardly imagine that this could have happened if the family living there was still established on the site,

9 VALLET 1999. 


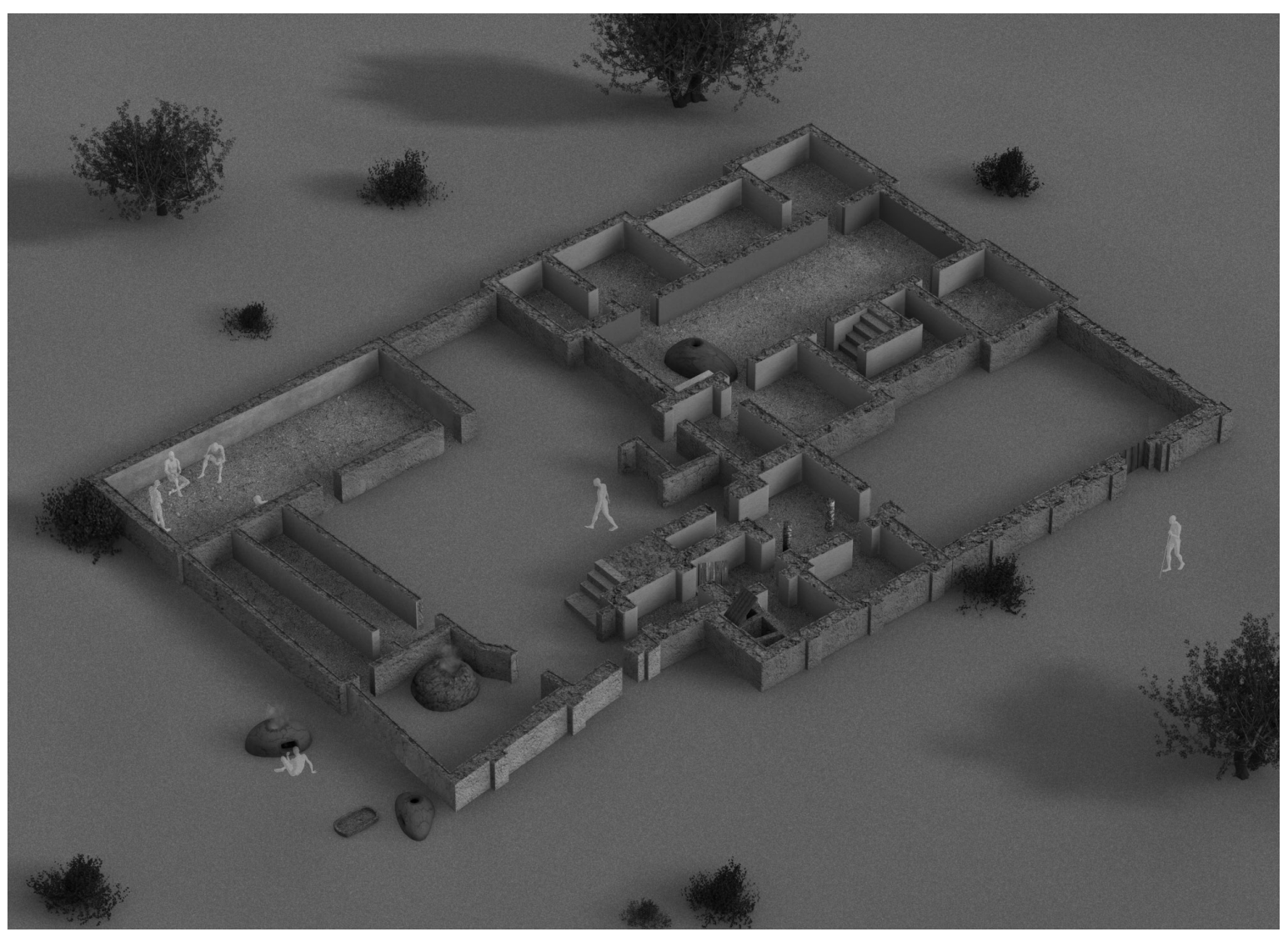

Figure 14: Axonometric view of the level 2B compound (LC3), from the southeast (@ Mission Tell Feres).

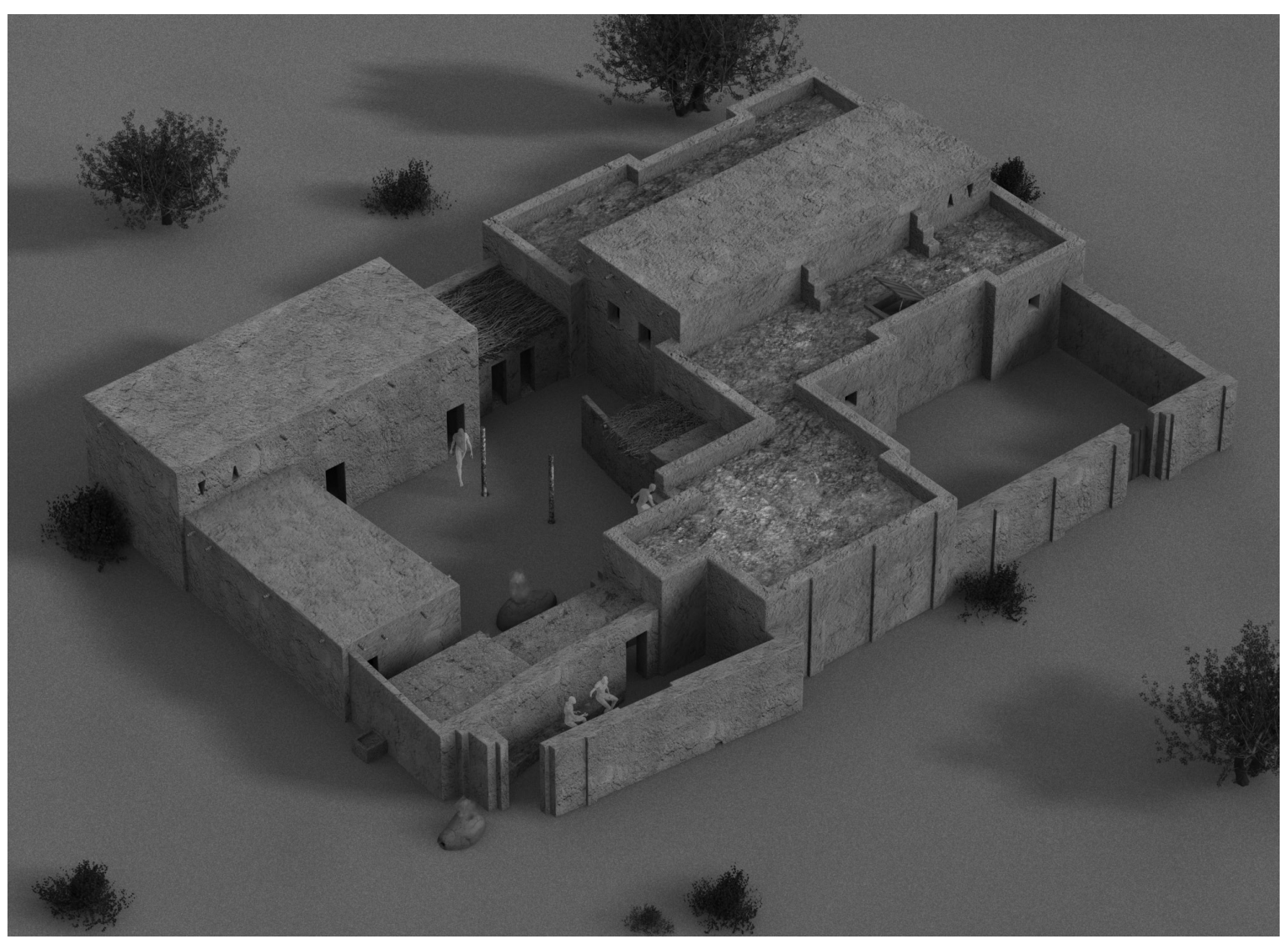

Figure 15: Reconstruction of the level 2A compound (late LC3) (@ Mission Tell Feres). 
and it may indicate, even if this is hypothetical, that what remained of the local elite (at least that family), finally left the village and settled at Tell Brak, because there was no future at Tell Feres. So with the compound of level 2, we could have a factual example of rural exodus, a phenomenon often evocated from a theoretical point of view (generally based on surveys) but rarely proven. In fact soon after, the rest of the inhabitants left the site (in level 1A, early LC5, only displaying pits) and founded a much smaller settlement on the western tell, where the modern village stands.

In conclusion, Tell Feres delivers much new evidence that provides significant insights

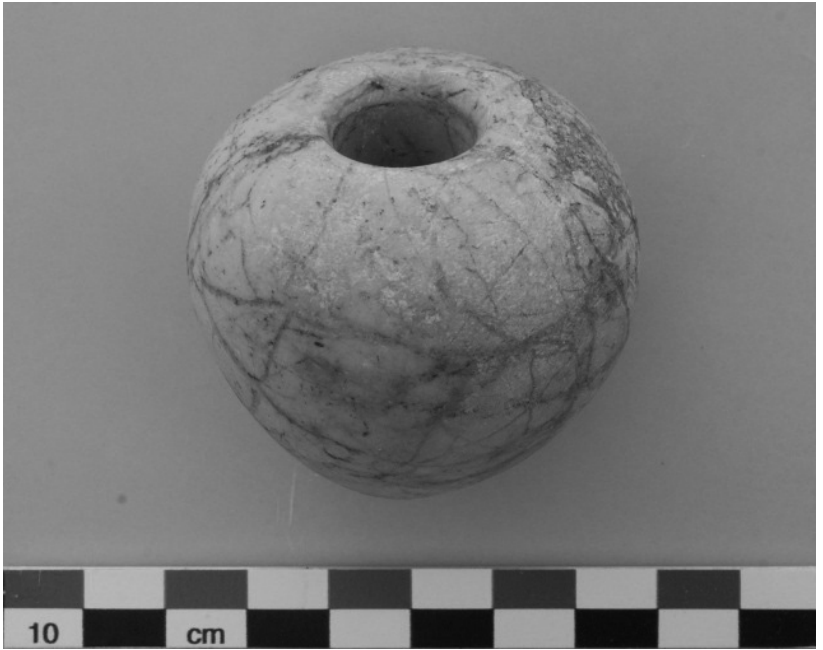

Figure 16: Mace head from level 2 (๔ Mission Tell Feres). into the formation of proto-urban society in Northern Mesopotamia. This process not only transformed a few main sites, such as Tell Brak, into the very first cities. It also had a major impact on the countryside, where the post-Ubaid settlements were progressively turned into satellite productive sites embedded in regional networks. From a strictly local point of view, Tell Feres is the story of a failure, a failed pathway towards urbanism. It reached a climax in Levels $6 / 5$ and then collapsed, because Brak was too close and probably developed faster. But the seeds of the empires to come in Mesopotamia were, in the second half of the fifth millennium, already planted.

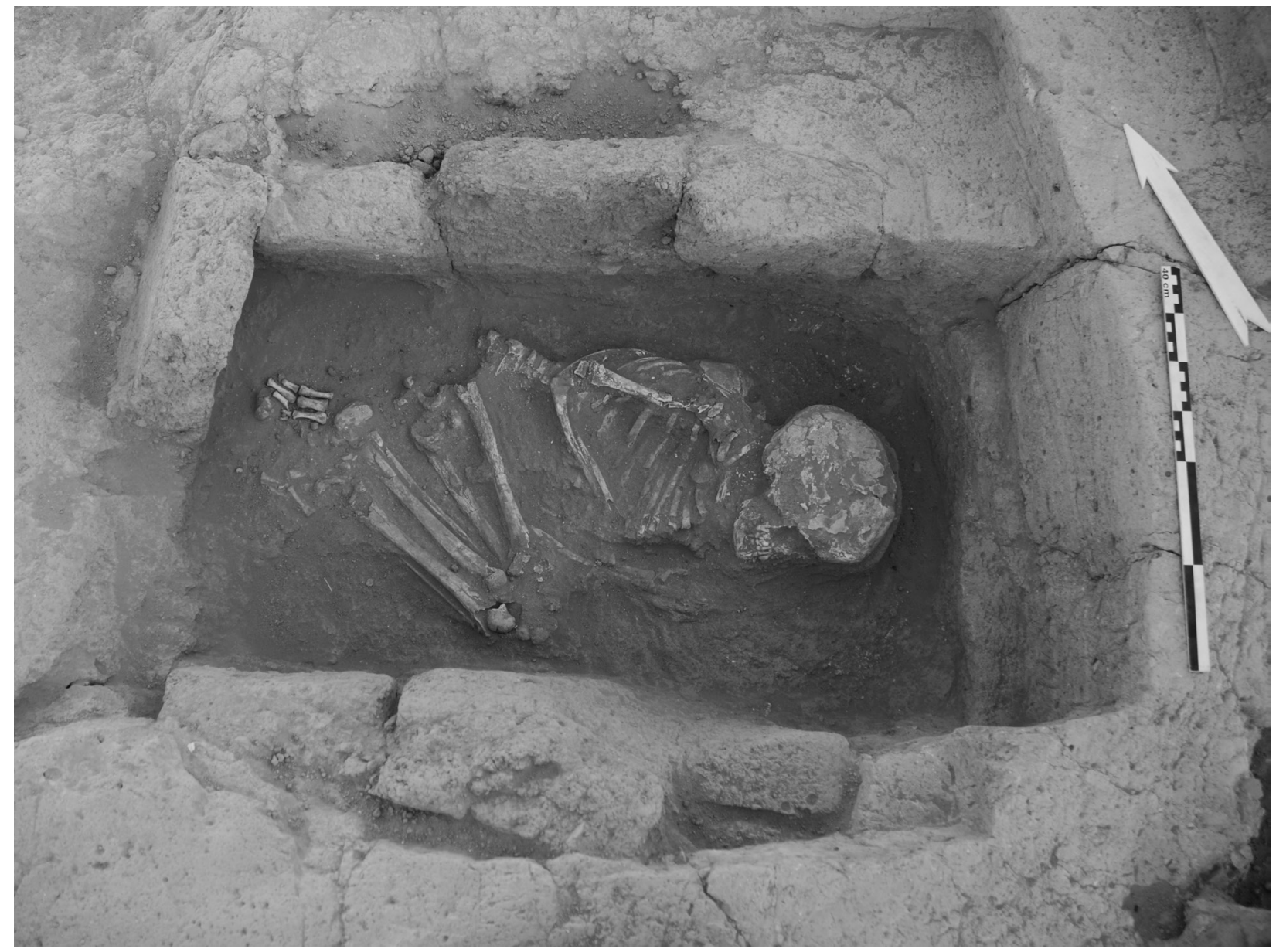

Figure 17: Infant tomb in room 13 of the level 2A compound ( Mission Tell Feres). 


\section{Bibliography}

BALDI J. S. 2015, Aux portes de la Cité: systèmes céramiques et organisation sociale en Mésopotamie du Nord aux 5ème et 4ème millénaires, Thèse de Doctorat, Université Paris 1 Panthéon Sorbonne.

FOREST J.-D. \& VALLET R., 2008a, "Urukian architecture from abroad: Some thoughts about Hassek Höyük", in J.M. CORDobA, M. Molist, M.C. PÉREZ, I. RUBIO, \& S. MARTINEZ (eds), Proceedings of the 5th International Congress on the Archaeology of the Ancient Near East, Vol. 2, Madrid, p. 39-52.

- 2008b, "Tell Feres al Sharqi : un site Chalcolithique Récent dans le Khabur (Syrie)," Paléorient 34/1, p. 191-198.

FOREST J.-D., VALLET R. \& BALDI J. S. 2012, "Tell Feres al Sharqi: A 5th-4th millennium site in the Khabur drainage basin", in MATTHEWS R. \& CURTIS J. (eds), Proceedings of the 7th International Congress on the Archaeology of the Ancient Near East, Vol. 3, Wiesbaden, p. 33-50.

FOREST J.-D., VALLET R., BALDI J. S. \& EMERY A. 2011, "Tell Feres al Sharqi, un site chalcolithique récent dans le bassin du Khabur (Syrie), synthèse provisoire au terme de trois campagnes (2006-2008)", Annales Archéologiques Arabes Syriennes LIII-LIV (2010-2011), p. 15-58.

KIRKBRIDE D. 1975, "Umm Dabaghiyah: a forth preliminary report”, Iraq 37/1, p. 3-10.

MCMAHON A. 2007, "Tell Brak 2007 final report", British School Archaeology in Iraq Newsletter 20, p. 5-12.

OATES J. 2002, "Tell Brak: The fourth millennium sequence and its implications," in POSTGATE J. N. (ed), Artefacts of Complexity: Tracking the Uruk in the Near East, Warminster, p. 111-148.

- 2012a, "Early administration at Arslantepe and Tell Brak (Ancient Nagar)", Origini XXXIV, p. 169-178.

- 2012b, "The Terminal Ubaid (LC1) Level at Tell Brak", in MARRO C. (ed), After the Ubaid. Interpreting Change from the Caucasus to Mesopotamia at the Dawn of Urban Civilization (4500-3500 B.C.), Papers from The Post-Ubaid Horizon in the Fertile Crescent and Beyond, International Workshop held at Fosseuse 29th June-1st July 2009, Paris, p. 65-86.

OATES J., MCMAHON A., KARSGAARD P., al-QUNTAR S. \& UR J., 2007, “Early Mesopotamian urbanism: A new view from the north", Antiquity 81, p. 585-600.

REICHEL C. 2011, “Hamoukar (2010)”, Oriental Institute Annual Report 2010-2011, p. 51-59.

Rothman M. S. 2002, Tepe Gawra: The Evolution of a Small Prehistoric Centre in Northern Iraq, University Museum Monograph 112, Philadelphia.

STEIN G. 2011, “Tell Zeidan (2010)”, Oriental Institute Annual Report 2010-2011, p. 122-139.

- 2012, "The Development of the Indigenous Complexity in the Late Chalcolithic Upper Mesopotamia in the 5th and 4th millennia B.C., An Initial Assessment", Origini XXIV, p. 125-152.

STEIN G., ALIZADEH A. \& RowAN Y., in press, Pathways to Power, Comparative Perspectives on the Emergence of Political Authority and Hierarchy in the Ancient Near East, Proceedings of the International Conference held on November 4-5, 2011, Chicago.

VALLET R. 1997a, “Habuba Kébira sud, approche morphologique de l'habitat”, in CASTEL C., Al-MAQDisSi M. \& VILLENEUVE F. (eds), La maison dans la Syrie antique du IIIème millénaire au début de l'Islam: pratiques et représentations de l'espace domestique, Actes du Colloque de Damas, 27-30 juin 1992, Beyrouth, p. 105-119.

- 1997b, "Habuba Kébira ou la naissance de l'urbanisme”, Paléorient 22/2, p. 45-76.

- 1998, "L'urbanisme colonial urukien, l'exemple de Djébel Aruda", in LEBEAU M. (ed.), About Subartu. Studies Devoted to Upper Mesopotamia. Volume I: Landscape, Archeology, Settlement. Subartu IV.1, Bruxelles, p. 53-87.

- 1999, "La formation de l'habitat urbain en Mésopotamie: Abu Salabikh, une ville neuve sumérienne", in BRAEMER F., CLEUZIOU S. \& COUDART A. (eds), L'habitat, source d'interprétation de l'organisation et de la complexité sociale en archéologie, XIXe Rencontres Internationales d'Archéologie et d'Histoire d'Antibes, Antibes, p. 151-165.

- 2014, "Tell Feres 2010: Recent Discoveries on the Ubaid and Late Chalcolithic in North Syria", in BIELIŃSKI P., GAWLIKOWSKI M., KolińSKi R., ŁAWECKA D., SOŁTYSIAK A. \& WYGNAŃSKA Z. (eds), Proceedings of the 8th International Congress on the Archaeology of the Ancient Near East, 30 April - 4 May 2012, University of Warsaw, Volume 2, Wiesbaden, p. 271-287.

Wright H., RUPLEY E. S. A. , UR J., OATES J. \& GANEM E., 2007, "Preliminary report on the 2002 and 2003 seasons of the Tell Brak sustaining area survey”, Annales Archéologiques Arabes Syriennes XLIX-L, p. 7-22. 
تل فرس Feres موقع نحو التمدّن في شمال ميزوبو تاميا

$$
\text { ريجيس فالي }
$$

يقع Tell feres في الجزيرة السورية، موقع يعتبر مفتاحاً لتحديد أنماطوجود التمدن في منطقة شمال بين النهرين، ميزوبوتاميا

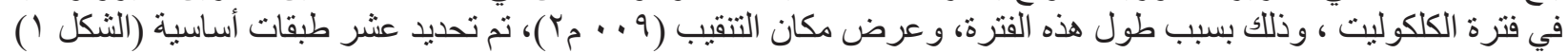

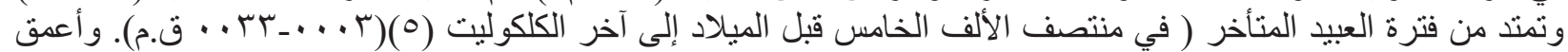

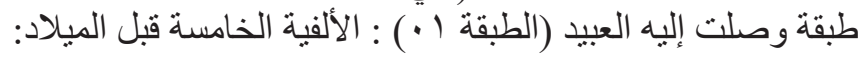

أفر ان ومو اقد لصناعة الفخار (الثكل r). كل و احدة من هذه الأفران تنتج في مرحلتين واحدة لتحضير الطين والثانية مقاعد لتجفيف الأواني.

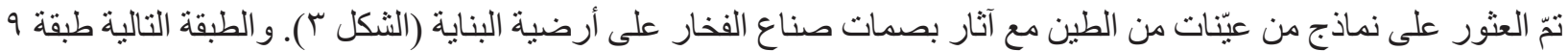

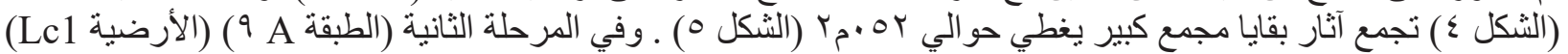

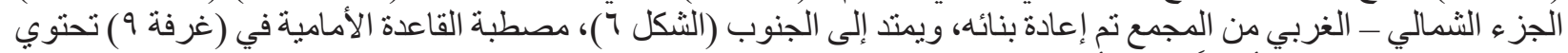

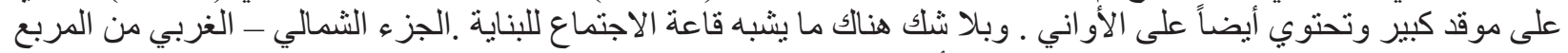

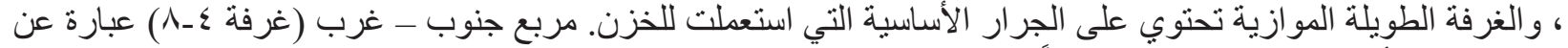
سكن اعتيادي أكثر من كونه مجمعا متنو عاً .

و هذا الجزء من البناية يبدو أنه مكان خاص لمعيشة الناس فيه ، على حد معرفنتا. البناية تجمع خلف حفرة بطريقة منتظمة منطقة

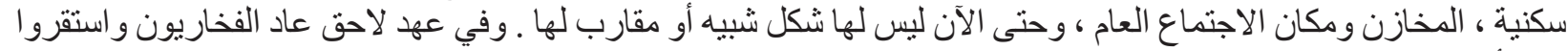

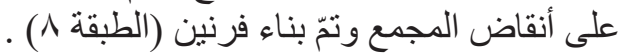

في (الطبقة V) مخازن الحبوب تغطي أنقاض أطلال المبنى ـ (الطبقة V) معروفة فيه فترة السكن و الاستيطان على نطاق واسع ،

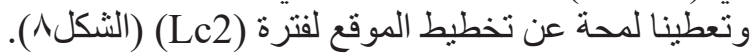

إلى الثمال توجد ورشة على شكل شبه منحرف مع فرن ضخدم مع جز ع من (دو ائر أو حفر مغلقة) مختلفة تستخدم للتخزين (الثكل

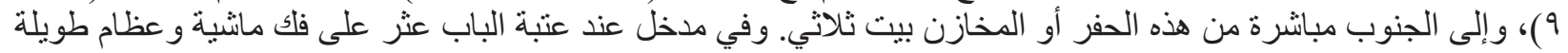

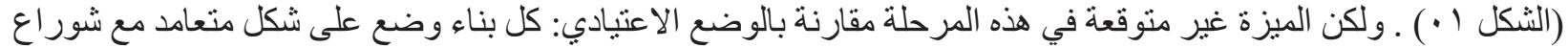

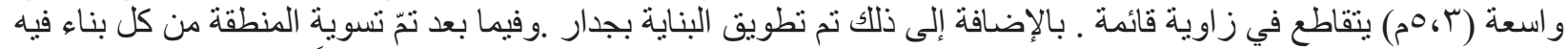

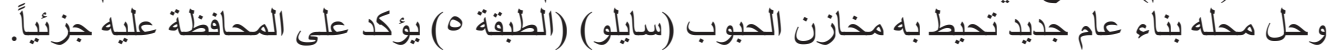

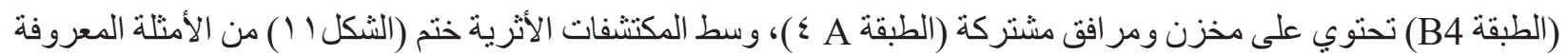

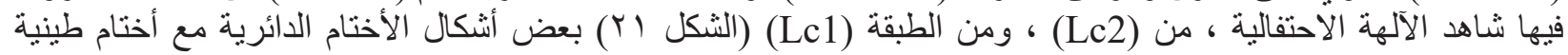

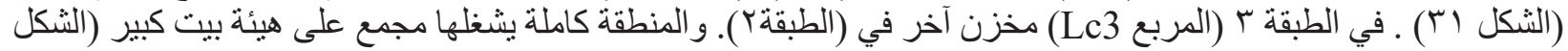

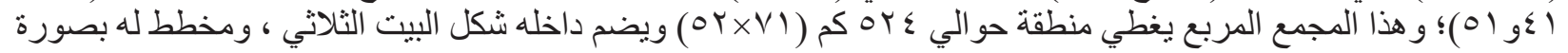

في البيت الثلاثي يمكننا متابعة التغيرات فيه إلى نهاية الغرفة خاصة مع تحديد المطبخ الذي تحول بمرور الوقت إلى الغرفة

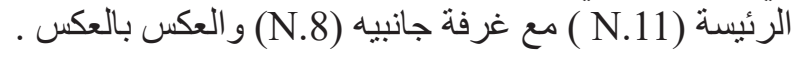

و أكثر الغرف الأخرى في المجمع استعملت للخزن ، وهذا واضح، فالخزن يحتاج إلى تجاوز مستوى البيوت وزيادة حجم الجرة .

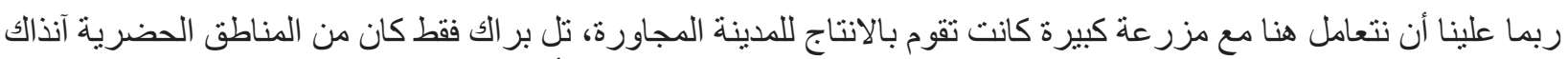

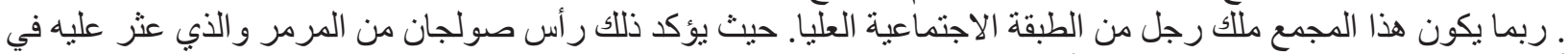

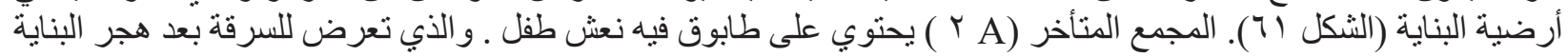

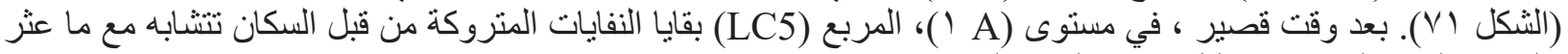
عليه في الجهة الغربية من التل، مكان القرية الحديثة. 


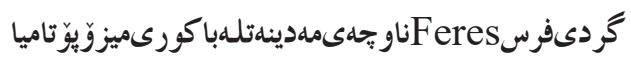

$$
\text { ريجسفالى }
$$

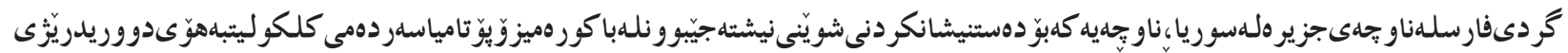

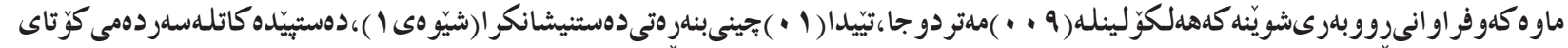

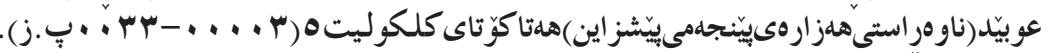

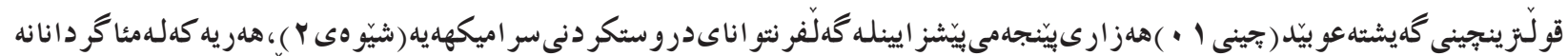

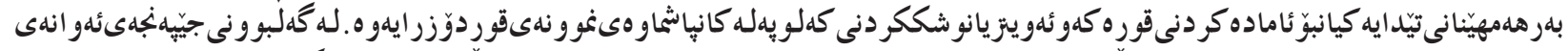

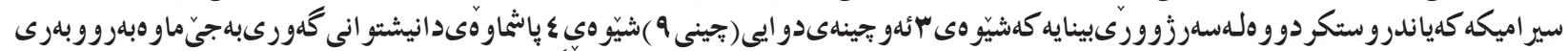

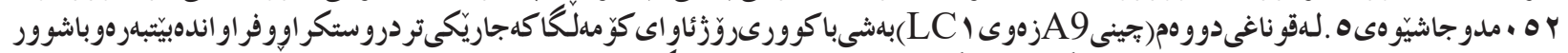

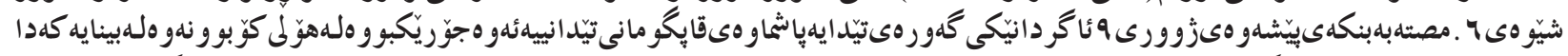

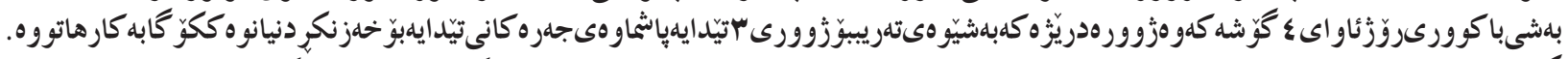

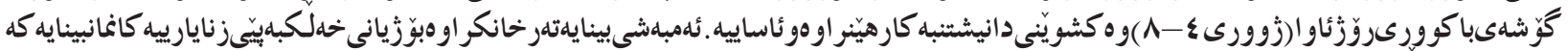

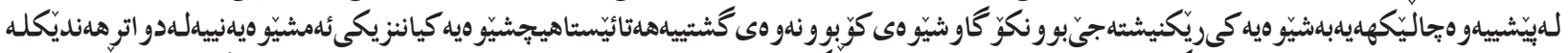

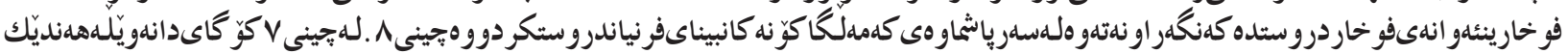

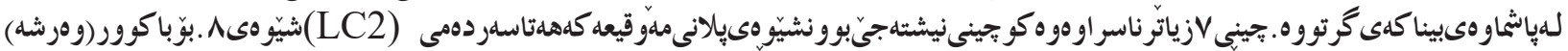

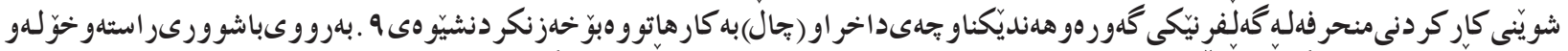

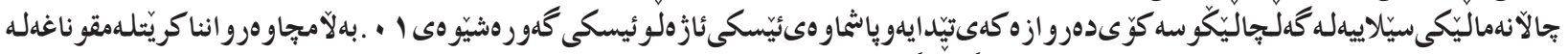

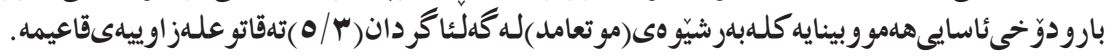

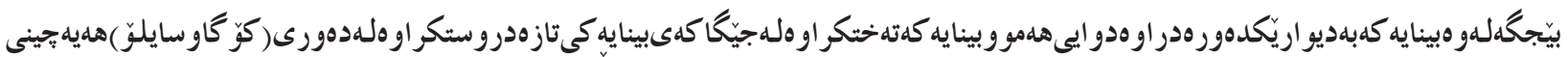

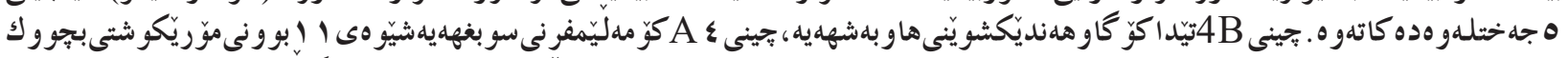

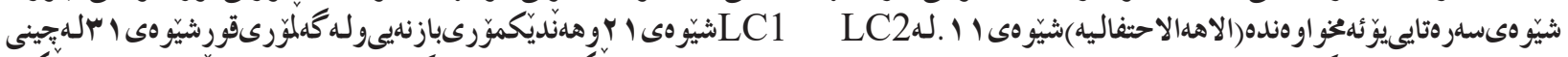

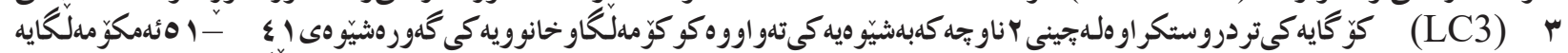

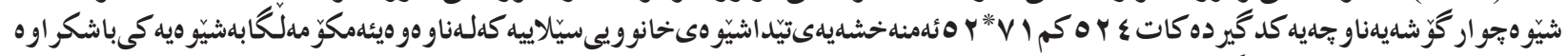

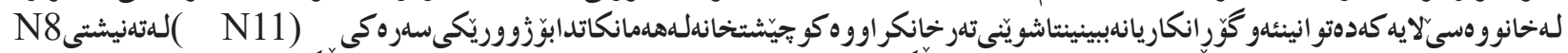

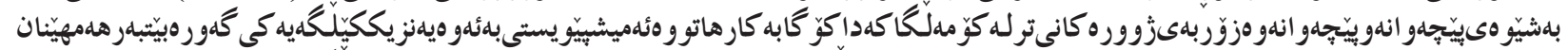

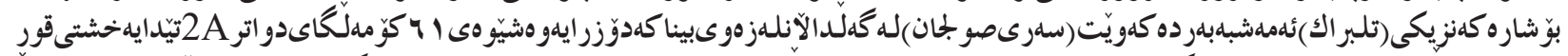

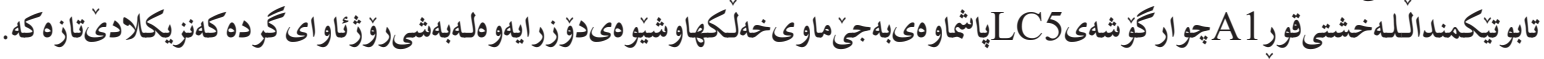

